\title{
O jornalismo político
}

O jornalismo deve ser considerado não só como uma instituição, mas também como instituição política; em outras palavras, os jornalistas são atores políticos. ${ }^{1}$ Isso não significa que os repórteres tenham lâminas políticas a afiar ou sigam conscientemente agendas partidárias ou ideológicas particulares. Ao contrário, o que complica estabelecer o papel político dos jornalistas é que sua influência política pode decorrer de sua adesão a princípios de objetividade e deferência aos fatos e sua distância "custe o que custar" em relação às consequências sociais e políticas de sua cobertura, e não a despeito dessa adesão.

Aqui temos que determinar exatamente o que é a "política". Afinal, se definirmos a política de maneira suficientemente ampla - como muitos fazem atualmente - fica difícil traçar qualquer limite útil, ou até estabelecer o que não é político em algum nível, e o termo perde qualquer valor prático. Essa tarefa é particularmente difícil porque, como William Connolly elegantemente sugeriu, "política" é a epítome de um "conceito essencialmente contestado". Sua complexidade multidimensional impede um fácil esclarecimento e assegura que uma tentativa de definir a "política" é em si mesma um ato político. ${ }^{2}$

\footnotetext{
Do original "The political news media", publicado como o capítulo 5 do livro Governing with the news: the news media as a political institution. Direitos autorais concedidos pela University of Chicago Press. Traduzido por Plinio Dentzien. Revisão da tradução por Luis Felipe Miguel.

2 "Para compreender a vida política de uma comunidade devemos compreender o sistema conceitual dentro do qual se dá essa vida; e, portanto, os conceitos que ajudam a dar forma ao tecido de nossas políticas entram necessariamente em qualquer relato racional sobre elas (...). Na medida em que o pesquisador assumir uma posição nesses contextos conceituais, e nós o soubermos, ele pode ser considerado como um participante em nossa própria política" (Connolly, 1983, p. 39).
} 
Para evitar solapar meu caso com um entendimento de "política" que não seja compreendido como tal por alguns leitores, concentrar-me-ei numa definição básica com a qual todos hão de concordar, mesmo que acrescentem áreas e ações adicionais que considerem como políticas. ${ }^{3}$ Começo pela venerável definição de David Easton: "O que distingue a interação política de todos os outros tipos de interação social é que ela é predominantemente orientada à alocação impositiva de valores numa sociedade." (Easton, 1965, p. 50) ${ }^{4}$ Embora a teoria sistêmica de Easton tenha sido corretamente posta de lado por não ser uma teoria empírica, sua definição de "política" é muito útil. Ela capta três processos diferentes. A política é relativa a escolhas para a sociedade. É também relativa às escolhas consideradas "impositivas", isto é, vinculantes para os indivíduos que não contestem independentemente as bases da escolha. E se utilizarmos a definição de dicionário de "alocação" para incluir tanto designação quanto distribuição é claro que a política estabelece o que é valioso na sociedade e também procura distribuir esses valores. Ao contrário da teoria de Easton como um todo, que sublinha a continuidade, sua definição de política não precisa preferir o consenso ao conflito. Boa parte da política pode se desenrolar tranquilamente. Mas se deixarmos de lado o resto da teoria de Easton em favor de sua definição, ela envolve os conflitos sobre quem ou o que é impositivo e também sobre quais devem ser considerados os valores centrais da sociedade.

Confesso certa simpatia com entendimentos mais amplos da política e do Estado, como os argumentos neomarxistas que apontam para a distinção arbitrária entre instituições públicas e privadas - ambas influenciam e corporificam os processos de decisão da sociedade. Nesse modelo, a mídia noticiosa seria parte do aparato do Estado ou ajudaria no processo de hegemonia político-cultural. No entanto, derrotaria meu propósito no longo prazo, dado que a mídia pode e deve ser produtivamente entendida como uma instituição política sob vários fundamentos teóricos.

\footnotetext{
A estratégia é semelhante ao modo como alguns cientistas políticos consideram, por exemplo, o "feminismo", focando naquilo com que todas as feministas concordam, ainda que algumas feministas prefiram ir além dessa definição tão básica.

4 A obra de Easton é extremamente útil, pois reconhece que as fronteiras em torno de "política" são permeáveis, fluidas e mutáveis. Sua cuidadosa consideração do que não é política, e onde podem ser traçadas as fronteiras para fins de análise, é especialmente benéfica em comparação com definições mais escorregadias. Ver Easton (1965, caps. 4 e 5) e Dahl (1963).
} 
Como entra o jornalismo na alocação impositiva de valores? Um modo é o reforço ao poder político ou de outra maneira a provisão de recursos a atores oficiais para seguirem suas agendas. Assim, muitos estudos sugerem que o papel político da mídia de notícias está em ampliar o alcance dos que já são politicamente poderosos. Nesse sentido, os jornalistas seriam influentes principalmente no apoio à autoridade oficial e menos na alocação de valores.

Mas o problema não é assim tão simples. O jornalismo é pelo menos parcialmente independente de suas fontes na produção do conteúdo das notícias. Em consequência, ela pode ser capaz de influenciar quem tem autoridade, quais são os valores da política e quais alocações são feitas. O jornalismo compartilha um destino semelhante com os três poderes constitucionais, sendo parcialmente independente e parcialmente dependente de outras instituições para cumprir sua própria tarefa.

Nesse sentido, podemos e devemos ir além da definição de Easton para afirmar que o jornalismo não é só política; nos EUA, ele se tornou parte do governo. ${ }^{5}$ Falar "governamental" é mais restritivo que falar "político". Por exemplo, movimentos sociais devem certamente ser considerados políticos, mas não governamentais. Embora algumas definições de governo se concentrem no papel da coerção, ${ }^{6}$ a linha difusa entre coerção e consentimento leva nossa atenção para o papel fundamental do comando impositivo e ordenado. A frase de Bert Rockman, "Em sua forma mais ampla, o governo constitui as instituições de governança” (Rockman, 1987, p. 257-260) não é tão tautológica como parece à primeira vista, se pensarmos a governança como o

\footnotetext{
Não quero me envolver nas batalhas terminológicas correntes sobre o significado de "política", "polis", "governo", "governança" e "Estado". Este último termo deve parte de sua popularidade recente na ciência política e na teoria política, pelo menos, à maneira ambígua como foi definido. Quase todos concordarão com uma definição de "Estado" que contenha um entendimento neo-weberiano de burocracias centralizadas e racionalizadas que exercem um monopólio da regulação, particularmente sobre os meios de violência e coerção. Ver, por exemplo, Hall e lkenberry (1989, p. 1-2). Mas a fronteira entre estado e sociedade civil tem sido sempre difícil de especificar e, como tais autores admitem, 0 poder do estado pode não emanar do próprio estado, mas de sua coordenação de outras fontes de poder. Embora a maioria dos autores veja o estado como um subconjunto do governo, até excluindo instituições como o legislativo, outros argumentariam que"o estado deve ser considerado como mais que o governo" Stepan (1978, p. xii). Dada a incerteza do termo e o rendimento pouco claro que seu uso fornece, não discutirei aqui a relação da mídia com "o Estado".

6 Tomemos a definição de Charles Tilly - seguindo Max Weber em seu foco sobre o controle da força organizada - como exemplo:"Para qualquer população específica, identifiquemos as organizações que controlam os principais meios concentrados de coerção; essas organizações são governos. Em qualquer população particular podem operar diversos governos - ou nenhum. Na medida em que tal organização for formalmente coordenada, centralizada e diferenciada de outras organizações, e territorialmente exclusiva, ela é um estado, mas muitos governos não são estados" (Tilly, 1978, p. 501-502).
} 
processo pelo qual as instituições públicas chegam a decisões impositivas sobre a vida pública a fim de alocar recursos públicos.

Qual é então a contribuição do jornalismo ao processo de governo? Para começar, devemos voltar às questões do viés e do impacto da mídia. Afinal, se o jornalismo tem sucesso - como muitas vezes afirma (Glasser, 1991, p. 784-786) - simplesmente espelhando um mundo exterior, então sua contribuição seria muito limitada. Volto-me então à política da cobertura das notícias, que empurra simultaneamente em duas direções. De um lado, o noticiário de fato trabalha para enfatizar a ação oficial e, portanto, implicar o jornalismo mais profundamente no governo. De outro, as notícias apresentam e interpretam tais ações por meio de valores de produção acordados, que contêm uma política implícita nem sempre favorável aos atores oficiais. Consequentemente, a notícia é o resultado de negociações recorrentes entre fontes e jornalistas, cujos resultados diários beneficiam apenas certas alocações de valores.

\section{Viés e impacto}

O noticiário é necessariamente seletivo. Os repórteres só podem atender a alguns dos eventos possíveis. Suas ideias formuladas e "vendidas", a amostra encolhe ainda mais. Na adequada frase de Gans, o noticiário é "a manchete da manchete": os repórteres destacam os elementos noticiáveis potenciais de um evento particular quando os "vendem" a seus chefes, que então escolhem entre aqueles ao decidir se aprovam a continuidade da matéria e como jogar com ela no contexto do produto noticioso como um todo (Gans, 1979, p. 92). O noticiário pode então não ser uma amostra representativa das ocorrências, mas os jornalistas podem responder com credibilidade - e o fazem - que chegaram com os eventos e pessoas mais importantes para incluir no noticiário. O problema, é claro, é que esse foco confere tanto status quanto o fato que teria levado a ele. Os jornalistas podem criar importância e certificar a autoridade tanto quanto refleti-la, ao decidir quem deve falar sobre o que e em que circunstâncias.

A seletividade, em si mesma, não leva automaticamente ao viés. Afinal, não obteríamos uma visão enviesada do mundo se as notícias tomassem uma amostra aleatória de todos os eventos possíveis a cada dia. A seletividade leva ao viés quando, dia sim, dia não, certos tipos de atores, partidos políticos e questões receberem maior cobertura e forem apresentados mais 
favoravelmente que outros. De fato, estudos documentam grande semelhança das notícias de dia-a-dia - histórias semelhantes com os mesmos atores, que produzem quantidades regulares de notícias. ${ }^{7}$ A dependência jornalística de rotinas significa que a maioria dos repórteres está em melhor posição para encontrar apenas algumas fontes e recolher apenas algumas notícias e está, portanto, mais inclinada a criar certos tipos de histórias.

Como alguns dos primeiros estudos sobre os vieses observaram, ${ }^{8}$ simplesmente mostrar que um ator político recebeu consistentemente cobertura mais favorável que outro não significa que a organização noticiosa é tendenciosa - implícita ou explicitamente - a favor ou contra um ou outro. Como argumentou o cientista político Richard Hofstetter, é preciso distinguir entre diversos tipos de vieses - viés político (derivado de preferências políticas individuais ou coletivas dos jornalistas); viés situacional (um ator político se engaja em comportamentos específicos menos ou mais bem situados para receber cobertura); e viés estrutural (atores políticos obtêm melhor cobertura correspondendo às demandas do meio de comunicação, inclusive na busca de histórias oportunas, claras, facilmente apresentáveis, vívidas, coloridas e visualizáveis). ${ }^{9} \mathrm{O}$ estudo cuidadoso de Hofstetter sobre a cobertura da campanha eleitoral de 1972 pelas três redes, dois jornais diários metropolitanos e um serviço telegráfico mostrou algum viés situacional e estrutural, mas pouco viés político.

Num nível mais profundo, o jornalismo é atraído para tipos específicos de histórias, com valores específicos, mais do que para outros. A lista dos "valores duradouros" de Herbert Gans, elaborada no início dos anos 70 - ordem social, liderança nacional, democracia altruísta, capitalismo responsável, individualismo, paroquialismo de cidade pequena e assim por diante - é facilmente reconhecível nos noticiários de meados dos anos 90, e ela revela não simplesmente o entendimento que os jornalistas têm de como o mundo funciona, mas também sugere uma concepção de como o mundo

\footnotetext{
Sobre a qualidade repetitiva das notícias, ver, especialmente, Darnton (1975); Phillips (1976); e Gans (1979, cap. 2).

Ver, especialmente, Weaver (1972, p. 57-74); Hofstetter (1976; 1978).

Hofstetter (1978, p. 3) operacionaliza agudamente as três formas de viés, observando que se pode identificar o viés situacional se eventos diferentes recebem cobertura diferente em diversas modalidades; o viés estrutural se os mesmos eventos recebem cobertura diferente em diversas modalidades; e o viés político como qualquer diferença residual, particularmente entre notícias que usam a mesma modalidade.
} 
deve funcionar (Gans, 1979, cap. 2). Gans especulou que o noticiário reflete as exigências reformistas da Era Progressista, quando as abordagens modernas do jornalismo se estabilizaram. ${ }^{10}$ Em consequência, os noticiários favorecem a política não partidária e aberta, suspeitam de grandes burocracias e empresas e celebram aproximações mais individuais que coletivas aos problemas públicos, a ponto de que poderiam ser chamados de "antipolíticos".

Entretanto, tais preferências raramente são explicitadas pelos jornalistas, seja em suas redes ou em autodefesa. De fato, as preferências dos jornalistas por certas histórias refletem uma ordem normativa mais por sua ênfase nas ameaças ou violações dessa ordem. Gans concluiu, por exemplo, que "os noticiários defendem a teoria democrática contra uma prática democrática quase inevitavelmente inferior" (Gans, 1979, p. 44). Isso significa que os jornalistas têm a opção de apresentar uma avaliação negativa dos poderosos, que aparentemente se acelerou a partir da década de 70, quando Gans fez sua pesquisa. ${ }^{11}$ Ainda que a ordem normativa da democracia altruísta seja assim defendida, tais notícias negativas não servem de conforto para aqueles que desejam acreditar que o sistema como um todo, e também os ocupantes dos postos de mando, está funcionando a contento. Dessa forma, os valores podem ser mantidos intatos, mas a expensas de uma crítica ao poder oficial.

Mas os "valores duradouros", normas que os pesquisadores identificam nos noticiários, têm pouco a ver com as normas que os próprios jornalistas especificariam se lhes fizéssemos a pergunta. O termo "norma" assim tem um status diferente para os cientistas políticos que estudam os jornalistas do que tem para aqueles que examinam outros atores políticos - pelo menos a julgar pela famosa obra sobre normas entre membros do Congresso nos anos 1950 e 1960 que especificou as normas e usos da casa (p. ex., reciprocidade, lealdade institucional, aprendizado, competência) a partir de observação direta, entrevistas e surveys ${ }^{12}$. Quando examinam seu trabalho e o de outros, os jornalistas falarão mais provavelmente sobre questões estilísticas (objetividade, especificidade, drama, excitação, boas imagens etc.) mais do que sobre noções políticas de como funciona ou deveria funcionar o mundo. ${ }^{13}$

\footnotetext{
10 A especulação de Gans (1979, p. 68-9 e 204-6) é reforçada por sua análise histórica, que documenta as mudanças durante a Era Progressista. Ver, por exemplo, Schudson, (1978) e McGerr (1986)

11 A melhor indicação da crescente negatividade das notícias está em Patterson (1993).

12 Os dois estudos clássicos sobre as normas congressuais na era pré-reformas são Mattheus (1960); e Huitt e Peabody (1969).

${ }^{13}$ Ver, em geral, Gans (1979, esp. cap. 5); Altheide (1976); McManus (1994); e Diamond (1995).
} 
Os valores de produção, parece, são pelo menos tão importantes - provavelmente mais - para os jornalistas quanto os valores políticos. Afinal, nas palavras do diretor político da Rede ABC, Hal Bruno, "Política é o que eu cubro. Jornalismo é a minha vida".

Como então conectar o trabalho que os jornalistas realizam com os produtos que criam? A resposta usual tem sido que as rotinas de trabalho dos jornalistas e do jornalismo contêm vieses implícitos. A busca de histórias e eventos dignos de virarem notícias não favorece igualmente todos os atores políticos em todas as questões. Dado que se espera em geral que os noticiários sejam tanto importantes quanto interessantes, os jornalistas esperam das fontes oficiais que lhes dêem pistas sobre eventos ou questões importantes, mas estão mais inclinados a reservar-se o poder de decidir se algo é suficientemente interessante para aparecer com destaque no noticiário.

Assim, enquanto os políticos ditam as condições e regras de acesso e indicam certos eventos e questões como importantes criando uma arena para eles, os repórteres podem tomar esse material (e o fazem) para decidir se algo é suficientemente interessante para ser coberto e depois construído como narrativa coerente. Os jornalistas contribuem com suas concepções específicas do que é digno de ser noticiado quando abordam seu trabalho. Nos termos de Gans, as fontes podem se por à disposição, e os repórteres podem estar sob considerável pressão para relatar sobre elas de maneira que as agrade. Mas as fontes não fazem notícia a menos que (e até que) os jornalistas considerem que tais notícias são apropriadas. Tais considerações obedecem a critérios institucionais do que faz uma história de qualidade e não aos fins políticos que as fontes buscam (Gans, 1979, p. 81 e caps. 4-5, passim).

O conflito faz assim parte do processo de produção da notícia. Acima de tudo, para qualquer meio jornalístico, o que quer que a fonte faça deve fazer parte de uma narrativa. A história deve ter não só protagonistas e antagonistas em conflito, mas as ações da fonte devem mover a história até um novo episódio. $\mathrm{Na}$ falta de tal movimento, os jornalistas tendem a concluir que "nada aconteceu" e, portanto, não há notícia ${ }^{14}$ - e se os jornalistas não consideram algo digno de ser noticiado por seu próprio julgamento, o poder da fonte pode não ser suficiente para ver esse algo impresso ou no ar. Em outros momentos, as fontes podem dar acesso aos jornalistas para um pro-

${ }^{14}$ Ver a discussão das fases em Fishman, 1980. 
pósito específico apenas para descobrir que sem querer ficaram disponíveis para ser questionadas sobre outras matérias que os jornalistas podem achar mais dignas de noticiar. Mesmo quando o acesso é limitado ou controlado, suas respostas podem ser postas em um contexto menos favorável.

Tal viés - e tal poder - pode ser controlado pelos jornalistas, não a despeito, mas por causa do poder da objetividade. Os repórteres se engajam na exclusão explícita de valores, aderindo à objetividade, ignorando as implicações de sua cobertura e seus próprios pontos de vista pessoais. Mas acabam por incluir implicitamente outros valores, aqueles inerentes às rotinas de trabalho e às definições do que faz uma história "de qualidade" (Gans, 1979, cap. 6). $\mathrm{O}$ aspecto indiscutido das notícias, de sua produção e do valor de publicá-las contribui para os relatos inconscientemente enviesados dos jornalistas, mesmo (ou até especialmente) quando eles aplicam critérios de objetividade e qualidade desinteressados e aparentemente neutros quanto ao conteúdo.

Esse conflito intrínseco leva a um processo de produção da notícia centrado no que chamei de "negociação do valor de notícia" (Cook, 1989, p. 169) $)^{15}$ - as negociações constantes, ainda que implícitas, entre fontes políticas e jornalistas. Com ambos os lados controlando recursos importantes, a negociação nunca é unilateral. Certamente, devemos adotar uma abordagem bem ampla de "negociação". Sem nos restringirmos à troca aberta sobre maneiras precisas de resolver problemas definidos em comum, sigo o caminho de outros que definem a negociação em termos amplos para abarcar não só toda a gama de interações, mas também como as partes de uma negociação aprendem mutuamente e prevêem como a negociação real será. ${ }^{16}$ Como observa o antropólogo P.H. Gulliver:

Durante toda a interação, as partes trocam informações, direta e indiretamente (...). A negociação é um processo de descoberta. A descoberta leva a algum grau de reorganização e ajuste do entendimento, expectativas e comportamento, eventualmente chegando a discussões mais específicas (...). (Gulliver, 1979, p. 70)

As fontes e os jornalistas têm interesse na cooperação e colaboração, particularmente na construção de uma relação estável, pela qual os jornalistas

\footnotetext{
15 Tuchman usou um termo semelhante para discutir o processo de negociação corrente dentro das organizações noticiosas; ver Tuchman (1978a, p. 31).

${ }^{16}$ Para uma resenha dessa literatura na psicologia social, ver Pruitt e Carnevale (1993).
} 
recebem informação em troca da publicidade que dão às fontes. Mas essas trocas são frágeis, porque esse interesse é pelo menos em parte contrabalançado pelas tensões entre o que as fontes desejam e o que os jornalistas querem das notícias. Uma noção mais ampla da negociação incluiria a troca estável e o sistema social em que tal relação ocorre, bem como os conflitos e trocas diretas sobre qual informação será dada sob quais circunstâncias. Mas não devemos negligenciar os modos pelos quais os jornalistas e atores políticos aprendem sobre o outro lado, às vezes quando mutuamente isolados. Assim, os atores políticos podem prever (e o fazem) o que provavelmente atrairá os jornalistas enquanto planejam suas palavras e ações; da mesma forma, os jornalistas podem prever (e o fazem) quais serão as reações de suas fontes à história que manufaturaram a partir da informação que obtiveram delas.

O resultado de todas essas negociações, direi, é um colorido político das notícias que favorece consistentemente apenas certas aproximações e resultados. Que esses problemas e questões cheguem ou não à agenda política americana através da mídia depende de duas coisas. Primeiro, as questões devem estar vinculadas a poderosas "fontes de autoridade". Segundo, devem estar ligadas aos critérios jornalísticos da notícia de qualidade. O poder político e o impacto político do jornalismo são, portanto, um tanto contraditórios. O primeiro serve para dar maior acesso às notícias - e, por extensão, à esfera pública - aos funcionários públicos, que por isso ganham recursos para dirigir atenção a problemas e questões específicas (e afastá-la de outros), para iniciar (ou encerrar) discussões e debates, e para enquadrar a responsabilidade e fugir às acusações. Mas o segundo implica que, embora os funcionários tenham facilitada sua entrada na esfera pública, não podem enviar sem filtro suas mensagens. Os valores de produção das notícias os dirigem - e a nós - a valores políticos específicos, não tanto empurrando a política para a direita ou para a esquerda, quanto para padrões de boas histórias que não levam a resultados políticos igualmente bons.

\section{Notícias oficiais}

Tendo estabelecido que o jornalismo não espelha simplesmente o mundo, podemos agora perguntar qual o papel que as notícias desempenham na alocação impositiva de valores. Comecemos pela "autoridade". Os jornalistas precisam cuidar, é claro, de quem ou o que tem suficiente autoridade para aparecer no noticiário, uma vez que a credibilidade dessas fontes se 
transmite a toda a reportagem. Consequentemente, os repórteres gravitam constantemente na direção de "pessoas na posição de saber", por meio do que poderão então se defender de críticas potenciais por terem dado tempo no ar ou espaço impresso a alguém que não o merecia. Essa preocupação com quem tem autoridade suficiente para ser citado nas notícias se revela no modo como as fontes são identificadas - como na televisão, onde os letreiros ao pé da imagem nos dizem não só o nome da pessoa que fala, como seu título ou papel estereotípico ("padrasto da vítima", "vizinho preocupado").

No entanto, nesse processo, os repórteres não refletem apenas a autoridade; eles também a reforçam. E, de fato, os repórteres tomam o cuidado de observar que quem quer que citem - até uma pessoa relativamente sem poder - está qualificado para discutir aquilo sobre o que fazem seu relato. Presumivelmente, os pais de alguém que foi assassinado podem falar com autoridade sobre a tristeza com a morte de um filho, ou alguém cuja casa foi destruída por um tornado pode falar com autoridade sobre sua decisão de reconstruir a casa. A distinção fundamental não é se fontes poderosas ou sem poder têm autoridade para falar, mas sua relação com os eventos que estão no noticiário. A pesquisadora da comunicação Grace Ferrari Levine documentou como, quanto mais poder têm as fontes, mais provável é que sejam mostradas como fazendo com que as coisas aconteçam, enquanto as fontes relativamente sem poder são retratadas como vítimas de eventos que lhes aconteceram (Levine, 1977, p. 100-105; Levine, 1986, p. 12-18, 23).

Assim, o primeiro viés importante do jornalismo americano é o foco na ação oficial, que forja o papel governamental dessa mídia. A interpenetração contemporânea da mídia e das instituições governamentais age, segundo a instigante frase de Blumler e Gurevitch, como uma "unidade sutilmente composta” (Blumler e Gurevitch, 1981, p. 467-493). Cada lado confia no outro na realização de sua própria tarefa.

Tomemos primeiro o jornalismo - lembrando que o jornalismo moderno nos EUA dá prioridade à coleta de informações de fontes que fornecem matéria bruta (ou, mais correto, pré-digerida) para reportagens. Para os repórteres setoristas, já vimos como a infraestrutura de relações públicas subsidia a produção regular de notícias e põe o desenvolvimento de cada dia no roteiro mais amplo da ação institucional.

A setorização da reportagem, como sistema, tende a gravitar em direção de instituições políticas quando define as responsabilidades dos repórteres. 
Os setores não só favorecem uma produção confiável de notícias sobre uma variedade de assuntos, mas também lhes dá certa variedade por meio das fontes citadas. A despeito da aparente variedade, contudo, a setorização ainda pode sobrerrepresentar pontos de vista particulares. Assim, em meu estudo dos primeiros dois meses de cobertura de TV depois da invasão do Kuwait pelo Iraque em 1990, a história da invasão e da resposta a ela foi dividida entre diversos setores: Casa Branca, Departamento de Estado, Pentágono, Congresso, empresas e o que chamei de "interior" - isto é, notícias que vinham de fora das conexões usuais em Nova York e Washington. Embora diferentes setores se concentrassem em diferentes atores ou aspectos (p. ex., Casa Branca dominada pelo Presidente Bush, o Pentágono com um grupo proporcionalmente maior de especialistas e analistas, o "interior" sendo o único lugar em que as pessoas comuns podiam entrar nas notícias etc.) e ressaltasse diferentes processos (p. ex. a política da Casa Branca, as políticas do Departamento de Estado, as operações militares do Pentágono), o sistema de setores sobrerrepresentava a política da administração, produzindo, entre os setores, uma compreensão complementar que sugeria que uma resposta militar à invasão era inevitável (Cook, 1994, p. 105-130).

Nesse sentido, devemos olhar para a setorização não só pelas notícias que torna possíveis, mas também pelas notícias que desencoraja. Por exemplo, a proeminência de seções separadas de negócios nos jornais e entre os repórteres de televisão presumivelmente torna mais fácil que os grandes dirigentes empresariais tenham acesso à mídia, do que, digamos, as lideranças sindicais, que raramente têm uma única página sobre trabalho para buscar atualmente. Tomemos a imagem evocativa de Tuchman de uma "rede de notícias":

Quanto mais estreita a trama da rede (...) mais pode ser capturado. Certamente, projetar uma trama mais estreita e mais cara pressupõe um desejo de capturar peixes pequenos e não lançá-los de volta ao fluxo das ocorrências amorfas do quotidiano. A rede de notícias dos dias de hoje pretende pegar os peixes grandes. (Tuchman, 1978a, p. 21).

Funcionários públicos são peixes grandes. Mas, além dos processos governamentais como assunto, e fontes oficiais como fontes úteis que possam ser citadas, o governo permite que os repórteres saibam quando a notícia acontece, onde eles se situam no desenvolvimento de toda a história, para 
onde o governo irá depois, e quais são as principais personagens - as fontes que estão "numa posição de saber", preferivelmente numa certa posição de poder dentro das hierarquias oficiais, ou numa posição de afetar o resultado final, como fornecendo uma mudança crucial de voto ou agindo como porta-vozes de um bloco reconhecido. O que é mais produtivo para os jornalistas é voltar-se para os atores oficiais que provavelmente discordarão (p. ex. Democratas e Republicanos, Congresso e Presidente, promotor e advogado de defesa, etc.). Como elegantemente propõe Mark Fishman, a discordância das fontes se torna "os dois lados da história"; qualquer acordo constitui "os fatos do caso" (Fishman, Manufacturing the news, p. 125).

Setoristas interagem com colegas de outras organizações jornalísticas e fontes, mas, em geral, na base de termos de acesso estabelecidos por atores políticos. ${ }^{17}$ Há então uma forte tentação a identificar-se com a fonte, adotando os valores e normas da instituição sob cobertura. Afinal, os repórteres devem tentar descobrir o que faz com que os atores institucionais ajam, e vender a história aos editores e produtores significa não só pôr aqueles indivíduos como protagonistas importantes, mas também adotar uma visão daquela instituição como parte central do jogo. Como resultado, nas palavras de Tuchman, setoristas "fazem as perguntas apropriadas ao mundo de suas fontes” (Tuchman, 1978a, p. 152).

Além disso, lidar com as fontes altera a dinâmica de criação das histórias, particularmente se essas fontes forem cooperativas e acessíveis - ou se puderem, mais tarde, vedar o acesso, caso suspeitem de tratamento injusto. Num simpósio de 1989, na Columbia Journalism Review, sobre a autocrítica da escritora Janet Malcolm segundo a qual a vida das fontes poderia ser apropriada para histórias jornalísticas, por exemplo, um repórter observou:

Acho que o jornalista tem uma responsabilidade de não levar vantagem, por causa de seu próprio artigo, dos tipos de coisas tolas, fracas, humanas que todos nós dizemos e fazemos no curso de nossas vidas... Para mim, isso seria um rompimento do tipo de contrato social estabelecido. Seria diferente se você estivesse escrevendo uma história sobre uma pessoa que não cooperou, o mesmo tipo de contrato não existe. (John Taylor apud Gottlieb, 1989, p. 21-35)

Sobre a organização social dos setores de notícias, ver, especialmente, Sigal (1973, cap. 3); e Fishman, (1980). 
Mas os setoristas não são os únicos que dependem de fontes oficiais. $\mathrm{O}$ mesmo vale para aqueles com menos autonomia (repórteres da editoria geral que recebem uma história particular de seus superiores) e para aqueles com mais autonomia (repórteres investigativos liberados da rotina do dia-a-dia). Gans esboçou bem as vantagens e desvantagens de confiar em repórteres setoriais ou repórteres da editoria geral; enquanto os primeiros são socializados numa cultura específica do setor e se inquietam em relação a seu continuado contato com suas fontes oficiais, os últimos "não precisam se preocupar em manter relações com pessoas que nunca mais encontrarão, e podem com maior facilidade fazer perguntas dirigidas, carregadas ou provocadoras" (Gans, 1979, p. 141). Esse potencial é, no entanto, contrabalançado pela falta de familiaridade do repórter da geral com qualquer um além das fontes mais óbvias - geralmente funcionários - e sua relutância em aprofundar-se por temor de que isso possa afetar sua capacidade de realizar a tempo a tarefa.

Até repórteres investigativos dependem de fontes oficiais. O legendário repórter investigativo Bob Woodward, do Washington Post, pode ser habilíssimo em obter informações, mas é sabido que ele utiliza as ferramentas do ofício dos jornalistas estabelecidos: entrevistar pessoas numa posição de saber sem ter que se dedicar à tarefa tediosa e frequentemente inútil de selecionar documentos. No melhor estudo sobre jornalismo investigativo, um grupo de especialistas com base na Northwestern University examinou uma série de casos em que eles tinham sido informados antecipadamente da história, permitindo-lhes mapear tanto seu desenvolvimento quanto o impacto na opinião da elite e da massa (Protess et alii, 1991). Testaram, especialmente, o que chamaram de "modelo da mobilização", pelo qual a mídia publica um malfeito e então o público responde, pondo pressão por reformas sobre os políticos. Contrariando a impressão de que os repórteres recebem uma informação anônima e se movimentam a partir daí, sua informação sobre os malfeitos depende muitas vezes da "cooperação constante de fontes oficiais - com maior frequência políticos e burocratas do que meros denunciantes - para obter documentos governamentais e citações para suas histórias" (Protess et alii, 1991, p. 21) ${ }^{18}$. O que surge é um “jornalismo de coalizão”, pelo qual políticos empreendedores e repórteres investigativos estabelecem um

${ }^{8}$ Observe-se que a conclusão de que, para que uma história se desenvolva, uma vez obtida a atenção dos jornalistas, ela tem que ser crível e factível, o que pode mais uma vez depender da cooperação de fontes oficiais, ou pelo menos da presença de documentos oficiais. (Protess et alii, 1991, p. 207-208) 
pacto que empurra um problema de política para o noticiário e melhora sua visibilidade e sua posição na agenda política (Protess et alii, 1991, caps. 9-10).

A predominância do que é oficial na produção americana de notícias pode também ser vista na dificuldade que tem a maioria das pessoas fora do governo de aparecer como fontes autorizadas. Funcionários do governo tendem a ser as fontes citadas com mais frequência nas notícias, especialmente em reportagens de Washington (Sigal, 1973, cap. 6; Gans, 1979, cap. 1; Brown, Bybee, Weardon e Straughan, 1987, p. 45-54; Berkowitz, 1987, p. 508-513). Em parte, ativistas não oficiais nem sempre estão organizados para chegar às notícias. ${ }^{19}$ Muitas vezes lhes faltam recursos para ter um porta-voz próximo a um telefone, mesmo que sua ideologia aceite e endosse tal hierarquia e especialização. Se os grupos tiverem esses recursos poderão escolher levar sua mensagem às pessoas diretamente via propaganda em lugar de depender do noticiário imprevisível. Em outros momentos, os ativistas podem se dividir sobre os benefícios de fazer parte do noticiário.

Além disso, ativistas não oficiais não estão em geral situados num setor do noticiário, dado que os setores de maior prestígio tendem a ser localizados em torno de instituições políticas, ou mesmo sociais (p. ex., medicina, direito) e não em torno de questões. Como resultado, a produção rotineira de notícias gera pouco envolvimento com processos e os eventos que os repórteres encontram e julgam dignos de figurar nos noticiários são em geral escassos. Sem capacidade para rotinizar a produção de notícias para seus fins, alguns grupos e movimentos nunca conseguem imaginar como fazê-lo. Como indica a pesquisadora da mídia e ativista Charlotte Ryan a partir de um de seus estudos de caso,

Esse nível de trabalho da mídia é a norma para muitas organizações - suas atividades só alcançam ocasionalmente os padrões de algo digno de figurar no noticiário

\footnotetext{
${ }^{19}$ Essas generalizações são extraídas de numerosos bons estudos das dificuldades que os atores políticos não governamentais encontram para chegar ao noticiário em seus próprios termos. Esses estudos incluem Peletz e Dunn (1969, p. 328-345); Goldenberg (1975); Molotch e Lester (1975); e, acima de todos, Gitlin (1980). Um livro recente sobre "como fazer" é também um belo esboço dos muitos obstáculos que os movimentos sociais enfrentam no uso dos noticiários; ver Ryan (1991). A certa altura, Ryan parece sugerir que não se pode esperar muito:"A vitória raramente é tal que o desafiante chega a status equivalente ao do dominante; em geral, apenas chega a não permitir que o dominante passe sem contestação" (Ryan, 1991, p. 70).

O melhor relato das estratégias de mídia dos grupos de interesse organizados é o de Schlozman e Tierney (1986, esp. cap. 8), embora as discussões em Walker Jr. (1991) sobre estratégias internas e externas sejam altamente instrutivas.
} 
da mídia, uma ou duas vezes por ano, se tanto. Isso traz prejuízos intrínsecos; seus membros dificilmente aprendem a manejar de maneira refinada as rotinas das notícias quando seu contato com a mídia é tão esporádico. (Ryan, 1991, p. 157)20

Em geral, ativistas só conseguem ser considerados dignos de figurar no noticiário sob certas circunstâncias. Primeiro, se cruzarem seus caminhos com os setores estabelecidos da mídia, nos quais os padrões do que vale a pena noticiar favorecem a especialização ditada pelo senso comum sobre como uma história no setor se desenrola. Os movimentos sociais muitas vezes recebem cobertura notavelmente diferente dependendo da percepção de seu alinhamento com as fontes oficiais. Um exemplo de divergência vem da desobediência civil em clínicas de aborto por parte do movimento "pró-vida", a Operação Resgate, em Wichita, no verão de 1991. Enquanto o repórter da $\mathrm{ABC}$ apresentava um relato frio e equilibrado que ressaltava (em imagens e palavras) a ordem mantida pelas demonstrações e o estímulo do governador "pró-vida" do Kansas, o relato da CBS era muito mais dramático, com closes dos manifestantes arrastados pela polícia e áudio do juiz federal local brandindo-lhes a lei (World News Tonight, ABC; e CBS Evening News, ambos de $1^{\circ}$ de agosto, 1991). No todo, a capacidade de os ativistas participarem de uma dada discussão no noticiário depende fundamentalmente de divisões oficiais que levam os repórteres a gerar o debate, o que está, em geral, como diz o cientista político Lance Bennett, "indexado" ao âmbito da opinião da elite (Hallin, 1986; Bennett, 1990, p. 103-125).

Uma segunda alternativa é arriscar notícias perturbadoras, que podem ganhar a cobertura sem controlá-la, especialmente se os repórteres se voltarem às fontes oficiais para interpretar a perturbação. Assim: manifestantes na Casa Branca serão quase sempre contrabalançados por palavras de algum porta-voz presidencial, quando todos sabemos que há abundância de notícias sobre a Casa Branca que não são automaticamente contrabalançadas por repórteres voltados aos eventuais manifestantes.

Terceiro, é esperar que ocorra um acidente que revele o problema que os manifestantes querem levantar. O noticiário acidental nos lembra que as fontes de autoridade nem sempre estão organizadas para alcançar o noticiário. Funcionários públicos obtêm acesso por sua capacidade de planejar as notícias de antemão; mas, quando acontecem acidentes, o noticiário pode

${ }^{20}$ Esse é também o tema de Goldenberg (1975). 
voltar-se para indivíduos ou grupos que em geral não chegam às notícias. Harvey Molotch e Marilyn Lester descobriram, em seu estudo pioneiro da cobertura do vazamento de petróleo de 1969 em Santa Barbara, que, à medida que o evento se distanciava no tempo, se reafirmou o compromisso profissional com as fontes oficiais, mas havia ao menos uma janela de oportunidade para que a oposição se fizesse ouvir, lançando dúvidas sobre a vontade que os funcionários teriam de minimizar o acidente (Molotch e Lester, 1975).

Para que uma história acidental tenha sequência ela deve ser empiricamente validada e ao mesmo tempo suscitar uma controvérsia ou uma resposta oficial. O estudo da cientista política Regina Lawrence sobre como o espancamento de Rodney King por vários policiais de Los Angeles se tornou uma notícia importante é especialmente intrigante ao mostrar o contraste com uma tentativa anterior do ativista negro Don Jackson para chamar atenção para a brutalidade policial na cidade próxima de Long Beach, quando provocou um espancamento com câmeras de vídeo rodando. A história de Jackson obteve um breve surto de cobertura da mídia, mas logo se extinguiu, porque os funcionários começaram a questionar a autenticidade do incidente; em contraste, o espancamento de King persistiu não só porque foi filmado por um estranho aparentemente objetivo, mas também porque funcionários em Los Angeles o utilizaram como uma indicação de problemas dentro do Departamento de Polícia da cidade (Lawrence, 1996, p. 437-454).

Uma quarta possibilidade é evitar de todo as notícias de primeira página, confiando na história de interesse humano, que permite a pessoas sem posições de autoridade figurarem no noticiário. Tuchman, por exemplo, admitiu que as "páginas femininas" nos primeiros tempos do movimento feminista podem ter posto as questões das mulheres num gueto, mas concluiu que, dada sua liberdade das rotinas padronizadas da produção de notícias, esse lugar ofereceu uma maior oportunidade para divulgar e discutir suas questões, oportunidade essa maior do que o movimento feminista viria a ter quando ganhou poder político e suas histórias foram transferidas para a primeira página (Tuchman, 1978b, p. 186-215). De modo semelhante, Gitlin documentou como a "descoberta" jornalística dos Students for a democratic society (SDS) em meados dos anos sessenta ocorreu com respeitosas histórias analíticas fora dos relatos-padrão no New York Times e CBS Evening News (Gitlin, 1980, cap. 2).

A predominância das vozes oficiais não se dá, porém, simplesmente porque é mais eficiente para os jornais focar-se nelas. Não só os funcioná- 
rios públicos são bem organizados para ajudar a subsidiar a imprensa, mas sua suposta autoridade permite que os repórteres construam um relato defensável. E, no mais básico, os jornalistas acabam julgando a utilidade da informação pelo menos tanto por quem a dá quanto pelo que ela é. Uma "fonte autorizada" é um indivíduo que ganhou um papel de liderança na narrativa do setor noticioso. Alguém num papel oficial na hierarquia do governo tende a dotar a informação com a credibilidade de sua posição na hierarquia e/ou com seu envolvimento no processo de tomada de decisão; essa mesma pessoa fora dessa posição dizendo a mesma coisa seria vista como se estivesse fazendo uma especulação ou espalhando um boato.

Mas o maior acesso das fontes oficiais ao noticiário não significa, contra o que pensam alguns entendidos, que o noticiário meramente apoia o status quo. Para tomar um exemplo, John Soloski prejudica o que seria de outra maneira um bom artigo, pelo silogismo incorreto: "Fontes de notícias, então, saem da estrutura de poder existente; logo a mídia de notícias tende a apoiar o status quo" (Soloski, "News reporting and professionalism", p. 215). A dependência dos repórteres em relação às fontes oficiais para informação e eventos encenados não determina o que eles fazem com o material bruto (ou pré-digerido) que recebem. Para entender isto, devemos considerar como os valores de produção dos repórteres influenciam o tom político e o impacto de suas reportagens. A alocação impositiva de valores pode não resultar da ação de repórteres abertamente preocupados com os valores políticos; em lugar disso, seus valores de produção podem levá-los a favorecer certas políticas e certos atores políticos.

\section{Valores de produção e valores políticos}

Quando a maioria dos estudos de observação participante de organizações de notícias, hoje clássicos, foi escrita nos anos setenta, os valores de produção pareciam ser menos fundamentais do que decisões relativas à importância. Para tomar um bom exemplo, Gans argumentava que os valores de produção entravam apenas quando as histórias se tornavam menos importantes (Gans, 1979, p. 157). ${ }^{21}$ Mas, desde então, a mídia jornalística mudou consideravelmente, com maior concentração da propriedade e administração mais orientada ao lucro. E o imperativo econômico de obter um

21 Seu termo para "valor de produção" é "consideração do produto". 
produto numa base regular que atrairá uma audiência que os anunciantes estão dispostos a pagar para atingir pode fornecer um contrapeso cada vez maior à dependência do mundo oficial. Juízos sobre importância podem não bastar, especialmente porque o equilíbrio que foi atingido nos anos setenta mudou nos anos noventa. Padrões de importância empalidecem agora ao lado do imperativo das histórias para as notícias das TVs locais; o decrescente corpo de repórteres das redes em Washington está sob crescente pressão de diminuir as reportagens; e até o austero New York Times, sob a liderança de Max Frankel, ao final dos anos oitenta começou a promover repórteres mais na base do estilo da prosa do que por furos substantivos. ${ }^{22}$ Além disso, o jornalismo como um todo se torna mais interpretativo, com menos histórias coladas às notícias do dia. Os jornais já tinham começado a cavar esse nicho quando ficou claro para eles que seus leitores já teriam recebido muitas das novas notícias da TV na noite anterior; agora, as três redes de televisão também estão se tornando mais interpretativas, com segmentos como as "Soluções" da ABC ou o "Olho na América", da CBS, focados nas "notícias que você pode usar" ou peças mais orientadas à narrativa, dado que as estações all-news no rádio e na TV podem ter chegado antes.

Enquanto o processo governamental fornece o palco, os atores e as falas para os relatos criados pelos jornalistas, cabe a estes cortar e colar esses elementos segundo seus próprios padrões de qualidade e interesse, que bem podem divergir do estado ótimo para os políticos. Lembre-se novamente a resposta dada por Lee Sigelman ao observar como repórteres da geral de dois jornais de Nashville com diferentes inclinações políticas podiam reivindicar tanto objetividade quanto autonomia: pense-se nos repórteres como artesãos comissionados para desenvolver um projeto (Sigelman, 1973).

A ideia de Sigelman também chama nossa atenção para um aspecto do trabalho deles que, como o historiados cultural Robert Darnton brilhantemente lembrou há mais de vinte anos, continua curiosamente a não receber atenção: os jornalistas reúnem histórias. Darnton se baseou em sua experiência como "foca" no Newark Star-Ledger e no New York Times. Numa anedota, Darnton não tinha conseguido matéria com nome assinado em sua breve carreira jornalística em Newark. Decidiu praticar com uma notícia policial sobre um menino cuja bicicleta tinha sido roubada num parque. Ele juntou uma história

22 Ver, respectivamente, McManus (1994); Kimball (1994) e Diamond (1995). 
e a mostrou a um repórter veterano, que lhe disse que ele a tinha escrito "como se fosse um press release" em lugar de uma história com carne e sangue. Sem se referir ao original, o veterano escreveu uma saga como amostra:

Toda semana, Billy punha seus vinte e cinco centavos no cofrinho. Queria comprar uma bicicleta. Finalmente, chegou o grande dia. Escolheu uma Schwinn vermelha brilhante, e levou-a para uma pedalada no parque. Todos os dias durante uma semana ele pedalava orgulhosamente no mesmo caminho. Mas ontem, três valentões pularam sobre ele no meio do parque. Derrubaram-no da bicicleta e fugiram com ela. Espancado e sangrando, ele voltou à casa de seu pai, George F. Wagner, na rua Elm, 43. "Não se preocupe, filho", disse o pai, "comprarei para você uma nova bicicleta, e você poderá usá-la na entrega de jornais para ganhar o dinheiro para me pagar". Billy espera começar logo a trabalhar. Mas nunca mais vai pedalar através do parque.

Darnton então telefonou ao pai para perguntar sobre dados novos a partir dessa história, sobre a mesada do menino, se a guardava num cofrinho, a cor da bicicleta e assim por diante. "Logo eu tinha detalhes suficientes para o novo padrão da história. Eu a reescrevi no novo estilo, e ela apareceu no dia seguinte, num quadro especial, acima da dobra, na primeira página, e assinada por mim" (Darnton, 1975, p. 190). Observe-se que Darnton não inventou nada. A história não era ficção; a fórmula chamou sua atenção para certas questões que poderiam ser usadas para revelar e recontar uma história familiar, mas verdadeira.

É claro que essa dimensão narrativa das notícias aparece mais (e é mais estudada) nas notícias de televisão. O estudo pioneiro do cientista político Edward Jay Epstein sobre o NBC News reproduz um memorando hoje famoso de Reuven Frank, então produtor executivo das notícias da noite:

Cada história no noticiário deve, sem qualquer sacrifício da probidade ou responsabilidade, exibir os atributos da fiç̧ão, do drama. Ela deve ter estrutura e conflito, problema e desenlace, ação crescente e ação decrescente, um começo, um meio e um fim. Esses não são apenas os elementos essenciais do drama; eles são os essenciais da narrativa. (apud Epstein, News from nowhere, p. 4-5)

E, de fato, as histórias dos noticiários de televisão podem parecer a última província dos estruturalistas, cheias de encadeamentos tese-antítese-síntese, até que a moral da história (o fecho da notícia) é enunciada pelo repórter, e 
a história é vinculada pelo âncora à próxima narrativa (ou por uma atração para manter o espectador sintonizado "depois dos comerciais").

O imperativo de contar histórias nos noticiários de televisão e rádio é particularmente proeminente dada a necessidade de manter as audiências sintonizadas. Mas o formato do noticiário de televisão é hoje tão difundido que foi adotado por noticiários que não compartilham a mesma motivação econômica - por exemplo, a CNN que, dado seu formato contínuo 24 horas por dia, estaria mais inclinada a esperar que o público zapeasse as notícias em vez de permanecer sintonizado num canal. ${ }^{23}$

As histórias de jornais também são histórias, apesar de que a forma de "pirâmide invertida" dos relatos - da informação mais central à mais periférica - não pareça ter muito a ver com a narrativa. Primeiro, qualquer história do noticiário tem as características da narrativa discutidas por Frank - protagonistas e antagonistas, conflito, movimento e solução (pelo menos momentânea). Além disso, para ser capazes de produzir notícias numa base regular, os repórteres gravitam na direção de sagas continuadas que podem lhes dar um processo de cobertura de mais de um dia. Isso não só ajuda a rotinizar os noticiários (gerando histórias para hoje e ajudando a gerá-las amanhã), como também lhes dá a chance de tentar realizar uma missão venerável do jornalismo - indicar onde as coisas estão e aonde vão, de tal modo que o público possa reagir de acordo e intervir, se necessário.

Mais que tudo, se os jornalistas puderem identificar uma história com continuação, serão capazes de determinar momentos dignos de noticiar e dar maior significação a eventos passageiros. Estudando os hábitos do corpo de imprensa de uma prefeitura, Fishman concluiu que os repórteres, diante de um processo institucional em andamento, constroem uma "estrutura de fases" ideal (presidentes ordenando e comandando, legislaturas aprovando leis, tribunais decidindo casos etc.) que pode ser fracionada em unidades separadas. As notícias acontecem quando o processo sai de uma das fases para a seguinte. De modo similar, Michael Schudson disse: "Perguntar 'Isso é notícia?' não é perguntar 'Isso de fato aconteceu?' É perguntar 'Isso significa alguma coisa?"' Ele dá este exemplo:

Histórias de eleição são fáceis de relatar, não tanto porque acontece algo digno de noticiar a cada dia numa campanha eleitoral (...). O repórter, o editor e o leitor sabem

${ }^{23}$ Em geral, ver Kerbel (1997). 
onde estão na história - perto do começo, no meio ou no fim. A história da eleição tem uma cadência, um ritmo e é mais fácil de ler e absorver porque os leitores podem acompanhar a batida. (Michael Schudson, "When? datelines, deadlines and history" apud Manoff e Schudson, 1986, p. 79-108, 98-99)

Essa ênfase em contar a história como maneira de dar sentido ao mundo não deve surpreender, dada a natureza "roteirizada" de grande parte da interação e compreensão humanas. ${ }^{24}$ Mas os noticiários não são feitos só de narrativas quotidianas. As histórias do noticiário de cada dia são episódios de sagas continuadas que ajudam a audiência a construir "metamensagens" (Robinson e Levy, 1986, cap. 7). De maneira simples, para que o noticiário seja produzido rotineiramente, os jornalistas devem ser capazes de visualizar cada episódio como uma simples parte de uma história maior e de imaginar um modo de mover a trama para o novo capítulo.

Consequentemente, a condição essencial das notícias não é o conflito em si e por si mesmo, mas uma série infindável de conflitos e soluções momentâneas. O conflito pode ser uma das poucas características das notícias em todas as culturas. ${ }^{25}$ Mas sem alguma solução à vista, o conflito não é digno de ser notícia, porque não leva a narrativa a um novo episódio. Um repórter a quem acompanhei durante um dia no Congresso em 1988 o dizia da seguinte maneira:

Julguei que a história do dia seria uma história da Casa Branca, que não há nada acontecendo, que as coisas andavam de qualquer maneira, que não há notícias (...). A Casa está chegando à resolução do orçamento, então devemos ter uma história. Com os contras, não há nada no nível de uma história, porque nada foi decidido (apud Cook, 1989, p. 50).

Uma demonstração recente de que o conflito sem movimento não faz notícia seria o impasse de fins de 1995 e início de 1996 entre o presidente Clinton e os republicanos do Congresso sobre os detalhes do projeto de orçamento equilibrado de sete anos. Depois de certo tempo, como as negociações não produziam resultado, o noticiário começou a se referir aos conflitos como "briga" e "disputa" ou simplesmente "confusão".

\footnotetext{
${ }^{24}$ Bom lugar para começar é o trabalho pioneiro de Schank e Abelson (1979). Ver também o trabalho muito acessível de Schank (1990).

25 Ver, por exemplo, Cohen, Adoni e Bantz (1990).
} 
Esta busca pela história é ainda mais intensa em outras formas de jornalismo que não estão tão "ligadas" em fatos novos como é, em geral, o caso dos repórteres setorizados. E aqui, seja nas reportagens especiais das revistas ou nas histórias perenes características que podem ser usadas para preencher espaço de notícias, o imperativo da narrativa é chave. O critério da importância desaparece quando nos distanciamos da primeira página dos jornais ou das histórias de abertura nos noticiários de televisão, elevando ainda mais o "interesse" como critério de qualidade, que foca mais nas características de boas histórias, como drama, cor, vivacidade etc., ou em histórias repetitivas que envolvem valores duradouros. No outro extremo, o jornalismo investigativo - no qual recursos consideráveis são gastos e a independência jornalística atinge seu ápice - requer uma trama clara com vilões e vítimas para que a história faça parte do noticiário. ${ }^{26}$

O imperativo de contar histórias, então, é forte em todos os noticiários o padrão conflito/solução da notícia, que cabe seja num único episódio de um enredo maior, seja na busca de "boas histórias" para encher o resto do jornal, revista ou transmissão, seja ainda na reportagem investigativa com vilões e vítimas. Mas, certamente, nem todas as narrativas são criadas iguais.

\section{A negociação da noticiabilidade}

Cada lado controla então recursos importantes. Precisamos agora considerar a maneira pela qual fontes e repórteres negociam as notícias, alocando, assim, valores. Conflitos surgem com funcionários públicos quando eles não dão aos repórteres material adequado aos valores de produção. Certamente, a centralidade da autonomia jornalística, como marca de profissionalismo e contribuição à satisfação com o trabalho, leva os repórteres há muito tempo a procurar distanciar-se das fontes, a levantar questões sobre o que as fontes dizem e fazem, e, em geral, a construir um relato tão independente quanto possível. Mas, além disso, se os repórteres estão sob crescente pressão para produzir mais notícias, eles podem ter que imaginar como fazer a notícia a partir do material ocasionalmente inadequado que as fontes lhes fornecem. (De fato, a lenda fala de repórteres que foram capazes de criar uma história

\footnotetext{
26 "A primeira tarefa específica em conceituar uma história investigativa é identificar os possíveis personagens e a linha da história. Pensando sobre sua informação inicial, os repórteres perguntam: Que histórias tristes podem ser contadas? Quem são os vilões? As vítimas? Nessa avaliação, os repórteres podem ver o núcleo de uma exposição. Alternativamente, a falta de um sentido de drama pessoal pode diminuir a saliência de uma história" (Protess et alii, 1991, p. 211-212).
} 
a partir de algo que nunca viraria notícia). ${ }^{27} \mathrm{O}$ outro lado é que indivíduos sem poder também podem chegar a notícias por conta própria, se (embora talvez apenas se) o material que oferecem for alto nos valores de produção que fariam a notícia interessante. Vemos essa dinâmica em ambos os extremos do espectro do poder - um, na Casa Branca, onde os presidentes nunca obtêm a cobertura que desejam (e acham que merecem); o outro, nos movimentos sociais, aonde chegar à notícia é esporádico e quase sempre nos termos dos repórteres, mas que podem formar a agenda e mudar os termos do debate.

A negociação sobre o que vale a pena noticiar ocorre simultaneamente em vários níveis. Um é a luta explícita sobre os fóruns em que as interações vão se dar, dado que funcionários e repórteres procuram especificar as condições e circunstâncias nas quais se encontrarão. Outro é a interação explícita nesses fóruns, exemplificada talvez pelo "toma lá dá cá" das conferências de imprensa. Finalmente, uma negociação implícita e indireta acontece quando cada parte da negociação está fora das vistas da outra - as fontes preveem o que virará notícia, e os repórteres voltam às suas organizações de origem com a matéria bruta, para dar-lhe forma como uma notícia coerente.

Antes de tudo, as fontes e repórteres negociam o processo da feitura da notícia. Tomemos fontes reconhecidamente autorizadas, usualmente funcionários públicos; os jornalistas precisam deles para criar eventos e responder a perguntas que poderão usar para construir suas histórias. No entanto, tais fontes provavelmente não terão portas abertas para todo e qualquer repórter. À medida que seu poder, autoridade e atração aumentam para a mídia, elas se tornam mais capazes de ditar os termos de acesso; de indicar que modalidades poderão ser utilizadas para registrar o encontro; para especificar se as perguntas serão registradas, não deverão ser-lhes atribuídas, serão em off ou entrarão como pano de fundo; de escolher quem fará as perguntas ou até se perguntas serão ou não permitidas num discurso, declaração ou oportunidade de fotografia; de decidir como responder e de decidir unilateralmente quando parar.

\footnotetext{
7 Assim, na página editorial do New York Times, um tributo ao lendário Harrison Salisbury reconta uma anedota sobre ele, abrindo assim: "Um grande jornalista pode tomar um tema trivial e transformá-lo em notícia de primeira página" ("A Salisbury scoop", New York Times, 11 de julho, 1993, p. 18). De modo semelhante, Darnton descreve um repórter que Ihe disse que seu momento de maior orgulho aconteceu quando ele foi cobrir um incêndio e descobriu que era um alarme falso. Ele então produziu uma história sobre alarmes falsos. "Sentiu que tinha transformado um assunto enfadonho em 'notícia' encontrando um novo ângulo" (Darnton, 1975, p. 187).
} 
Conferências presidenciais de imprensa são provavelmente o formato mais conhecido disso. Os presidentes, e não os repórteres, decidem quando elas serão realizadas. Elas podem começar com uma declaração que mais ou menos formula a agenda para a interação, reconhece os jornalistas (às vezes fazendo-o para mudar de assunto ou para obter uma questão mais leve), pode decidir aceitar mais uma pergunta sobre o assunto, pode gastar o tempo com respostas evasivas e pode suspender o processo depois de certo número de perguntas. ${ }^{28}$ Embora as conferências presidenciais de imprensa estejam estabelecidas ao ponto da institucionalização, outros funcionários têm liberdade de improvisar. Assim, durante suas primeiras semanas como líder no Congresso, Newt Gingrich dava informes oficiais diários à mídia, como seus predecessores, mas com a diferença crucial de que a televisão era convidada, até que as perguntas ficaram cada vez mais distantes da agenda que ele queria seguir, e então os informes foram sumariamente cancelados. E, se os presidentes se sentirem desconfortáveis no "toma lá dá cá" das conferências de imprensa, podem substituí-las por outras formas de comunicação que permitam ainda menos participação dos jornalistas.

Certamente, há limites ao que as fontes oficiais podem fazer. Por exemplo, os presidentes, apesar de ocasional retórica contrária, raramente congelam repórteres ou questionam suas credenciais. Ataques a jornalistas individuais são igualmente considerados inadequados. E se os jornalistas se sentirem abertamente pressionados, eles sempre podem mostrar os esforços para calá-los - como fez um repórter da CNN no início de 1993, quando o então diretor de comunicações do presidente Clinton, George Stephanopoulos, foi filmado escondido atrás de uma câmera explicando ao repórter da CNN encarregado da Casa Branca, Wolf Blitzer, de que o presidente nunca dissera o que Blitzer estava alegando.

Mas os jornalistas não têm muita força com os funcionários na negociação do processo. Só quando ele são considerados menos cruciais para as notícias é que os repórteres podem expressar opiniões sobre o modo de encontrar e interagir com suas fontes. Os correspondentes da Casa Branca têm sido identificados como exemplares de jornalismo reativo; alguns observadores veem o jornalimo como extensões virtuais da Casa Branca, atuando em bando, que raramente questiona a agenda do presidente e que voluntariamente

\footnotetext{
28 Sobre entrevistas coletivas presidenciais, ver, entre outros, Cornwell (1965, p. 142-207); Manheim (1979, p. 55-74); Grossman e Kumar (1980, p. 241-248).
} 
participa de oportunidades de fotografias e outros eventos de mídia. ${ }^{29}$ Mas, ao enfocar exclusivamente as negociações do processo, nas quais os funcionários têm uma vantagem, tal visão subestima a capacidade dos jornalistas dominarem em outra fase da negociação: a do conteúdo - sobre o que será a história, e se ela será positiva, negativa ou neutra.

A negociação do conteúdo é menos dominada por fontes autorizadas, porque elas não podem controlar tão facilmente o que outras fontes estão dizendo, quanto mais que outras histórias são relatadas por outros setores em Washington, em todo o país e à volta do globo. Grandes histórias podem surgir, desviando a atenção de eventos cuidadosamente arranjados.

Mesmo em histórias estimuladas por fontes autorizadas, em fóruns que elas controlam, os repórteres podem (e o fazem) "tecer" comentários e citações recolhidas por eles mesmos ou por seus colegas em suas reportagens. Assim, as muitas vantagens que os funcionários têm na negociação do processo não se generalizam. Por exemplo, o acesso livre que os repórteres de Washington têm a grande número de congressistas significa que, embora o próprio Congresso esteja menos no noticiário, os jornalistas facilmente podem obter pistas sobre a opinião congressual sobre ações presidenciais. ${ }^{30}$ Além disso, como os jornalistas precisam achar conflito para relatar, a dependência em relação ao Congresso pode ser adequada a dois roteiros-chave de Washington: democratas versus republicanos e Congresso versus Presidente. Acrescente-se a isso a pletora de grupos de interesse que soltam seus press releases, os especialistas cujo emprego inclui fornecer análises incisivas (ou apenas loquazes) e a sempre presente possibilidade de fazer uma coleta de opiniões ou ir para o interior e ver como respondem as pessoas comuns - e até o poder do presidente sobre a totalidade do noticiário pode ser bastante limitada.

Tudo isso quer dizer que, a despeito da sala de imprensa hermeticamente selada da Casa Branca, as notícias do setor Casa Branca nem sempre são notícias a partir da perspectiva escolhida pela Casa Branca. Relatei em outro lugar um estudo de sete diferentes eventos presidenciais de mídia, tais como registrados em C-SPAN, e a cobertura das mesmas nos noticiários noturnos das redes nos seis primeiros meses da presidência Bush (escolhida por causa da diversidade

\footnotetext{
29 Retratos particularmente fortes aparecem na clássica observação participante de Timothy Crouse (1973); e nas entrevistas realizadas por Mark Hertsgaard (1988) com funcionários e repórteres na administração Reagan.

30 Hess descobriu que o "Congresso é o local dominante da coleta de notícias" (Hess, 1981, p. 48).
} 
de fóruns que Bush utilizava, e a percepção dos repórteres de uma relação mais aberta, variada e amigável, comparada com seu predecessor e seu sucessor). Em todas as histórias, as citações presidenciais consistentemente ocupam muito menos da metade do tempo dos relatos dos repórteres da Casa Branca, e é raro que mais da metade das imagens sejam do presidente. Em outras palavras, a maior parte das histórias da Casa Branca é feita com áudio e vídeo de outras fontes - membros do Congresso, especialistas, tomadas de arquivo ou os próprios jornalistas. E os jornalistas podem ser altamente seletivos, não só a respeito de quem mais citar, mas também do que mostrar da própria exposição presidencial. Nos exemplos de Bush, os noticiários noturnos nunca incluíam mais do que $10 \%$ do número total de segundos das declarações presidenciais ou da imagem presidencial contidas no evento original (Cook, 1996).

Posto de outra maneira, as fontes oficiais podem instigar e dirigir a atenção dos repórteres para eventos ou questões particulares, sem, no entanto, controlar a história final. Cada lado depende do outro na negociação do que vale publicar, e nenhum dos dois domina plenamente, porque os funcionários e os repórteres partem de instituições pelo menos parcialmente independentes, que comandam importantes recursos específicos.

Os jornalistas se preocupam em manter o acesso a fontes poderosas, mas só se esse acesso levar a um produto que seus superiores - que, afinal, pagam seus salários - avaliem favoravelmente. Eles têm que obter histórias que maximizem os valores de produção de vivacidade e clareza paralelamente às normas jornalísticas de equilíbrio e neutralidade. Dada a satisfação e autoestima que os repórteres ganham com sua autonomia profissional, qualquer indicação de que são meros agentes do presidente levaria à perda de prestígio dentro de uma profissão que carece de marcadores tradicionais de pertencimento e realização. Finalmente, mesmo que as fontes possam restringir o acesso e dirigir a atenção para tópicos específicos, a mídia noticiosa tem a última palavra sobre o produto final - levantando outras questões e dúvidas, questionando motivos e procurando fontes críticas em nome do equilíbrio.

Às vezes essas fontes críticas não são fáceis de encontrar; e é claro que, seguindo a hipótese da indexação de Bennett, o âmbito mais amplo de opiniões surge no noticiário quando há desacordo entre as elites. ${ }^{31}$ Esse padrão

${ }_{31}$ Para uma consideração recente do estado da literatura sobre essa hipótese, ver edição especial de Political Communication, "Journalism norms and news construction: rules for representing politics", 13 (1996, p. 371-481), organizado por W. Lance Bennett e eu mesmo. 
é mais visível em guerras e crises internacionais. Assim, as críticas à guerra do Vietnã surgiram apenas quando as fontes do Congresso começaram a levantar dúvidas sobre as estratégias presidenciais. Da mesma forma, vozes críticas só surgiram nos noticiários durante o início da guerra do Golfo quando o Congresso apresentou dissensão, e tão logo o Congresso apoiou a opção militar, o foco dos noticiários se afastou do debate, na direção de considerações operacionais. ${ }^{32}$

Quando os jornalistas tomam a iniciativa de construir suas histórias com resultados não desejados por suas fontes ficam vulneráveis à pergunta: "Quem os elegeu?" Em geral, eles inventam modos, nas palavras de Don Hewitt (produtor executivo de 60 Minutes), de "ser críticos sem ser partidários", porque sua legitimidade se baseia em não ser vistos como atores políticos autônomos. Assim, eles têm que descobrir como fazer uma cobertura crítica que não possa ser tida como uma vingança politicamente fundada - seja com base no dissenso já existente, seja por julgar os funcionários pelos padrões que eles mesmos estabeleceram, seja ainda criticando mais o estilo e os métodos do que a substância e os objetivos. Mesmo numa crise de política externa, o jornalismo está longe de ser acrítico. Como bem documentou o cientista político Jonathan Mermin na cobertura da invasão do Panamá em 1989 e na Guerra do Golfo, a falta de debate sobre o acerto da política não impede que os repórteres critiquem os meios, levantando dúvidas sobre a capacidade do Presidente Bush alcançar os objetivos a que se propôs (Mermin, 1996, p. 181194). Tal abordagem faz pleno sentido, dado que permite que os jornalistas incluam tensão e conflito que estariam de outra maneira excluídos de suas histórias, e também dá aos repórteres um modo de realizarem um ritual político que os distancie de suas fontes. E, como aponta Mermin, tais notícias ajudam a explicar por que os funcionários do governo se queixam sobre notícias que pareceriam muito positivas a observadores externos (inclusive acadêmicos); praticamente nenhuma notícia aparece como as fontes de fato prefeririam.

A contribuição jornalística para as notícias é até maior em outras circunstâncias, o que não é surpreendente: por exemplo, quando os repórteres podem escolher entre várias fontes autorizadas; quando podem comparar o desempenho presente com promessas passadas; quando têm outras histórias para entretecer; e assim por diante.

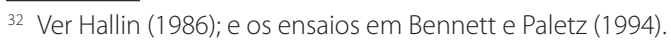


Mais importante, os repórteres podem ainda ser forçados a discordar da versão oficial dos eventos, se tal versão não alcança os padrões definidos pelos valores de produção. Voltemos aos sete eventos de mídia do primeiro ano do mandato de George Bush. ${ }^{33}$ Em meu estudo, sugeri que esses eventos poderiam ser cobertos de quatro maneiras diferentes: primeiro, adequando todos aos interesses do presidente; segundo, onde o presidente pudesse ceder ao jornalismo a definição do evento particular, de tal modo que pudesse avançar em seus interesses maiores; terceiro, onde o controle presidencial das imagens mais fortes pudesse rivalizar com o controle jornalístico do texto falado; e quarto, onde o presidente tivesse que ceder ao jornalismo a definição do evento como um todo. Dos sete eventos de mídia, Bush foi mais capaz de controlar as notícias adequadas ao roteiro presidencial de ação e ordem decisiva quando enviou 2000 soldados ao Panamá (antes da invasão) para proteger - ele declarou - vidas americanas.

Igualmente instrutivos são os eventos em que Bush perdeu o controle sobre a definição. Numa delas, Bush visitou o Pentágono para simbolizar apoio ao seu indicado a secretário da defesa, John Tower, muito contestado; a oportunidade de foto se tornou uma parte menor da história no Senado, onde a indicação esteve à beira da derrota. Não apenas o prosseguimento da saga esteve ligado ao movimento no Congresso. Bush não fez declarações, exceto para admoestar um repórter que, disse ele, "aparentemente não conhece as regras”. As imagens de vídeo da carreata de Bush recebida por Tower e de Bush e de Tower sentando-se foi insípida. Bush foi não só relegado a poucos segundos no ar durante o debate no plenário do Senado, mas os repórteres cortaram até esse gesto ao observar novamente que se tratava de um evento contestado e fracassado. ${ }^{34}$

Outro dos sete eventos foi uma visita formal do Primeiro Ministro japonês Takeshita à Casa Branca, bom exemplo de uma ocasião oficial com pouco valor como notícia. Em suas seções visual e falada, foi repetitiva e afetada,

\footnotetext{
33 Para uma análise mais completa, ver Cook (1996).

34 Tomei emprestada a expressão"evento fracassado" do valioso trabalho de Kiku Adatto sobre a campanha presidencial de 1988. Ver Adatto (1990). No caso Tower, Bob Schieffer, para a CBS, observou:"O presidente foi ao Pentágono para mudar a marcha com uma demonstração de apoio", acrescentando então o som do Vice-Presidente Quayle: "Acredito que em certo período de tempo, os números continuarão diminuindo". Andres Mitchell narrou o trecho sarcasticamente para a NBC dizendo:"O Presidente dos Estados Unidos simplesmente passou pelo Pentágono para ver seu disputado indicado para o Departamento de Defesa no trabalho - uma chance de foto cuidadosamente arranjada", antes de se voltar para o debate no plenário do Senado (CBS Evening News, NBC Nightly News, ambos em 3 de março, 1989).
} 
com "cabeças falantes" e sem ação viva. O evento não deu movimento à história das relações entre o Japão e os Estados Unidos. Presumivelmente, se os jornalistas tinham que cobrir tal evento, teriam que encontrar maneiras criativas de trabalhá-lo como um evento mais digno do noticiário.

Em sua totalidade, o evento desdobrou-se assim: o carro de Takeshita chegou à frente da Casa Branca e ele entrou no prédio; ele ressurgiu na sacada com Bush para uma foto, e Bush, olhando em volta em busca de algo para fazer, respondeu a uma só pergunta sobre sua saúde, dizendo apenas, "Homem totalmente novo. Tudo bem. Totalmente recuperado". Mais tarde, Bush e Takeshita reapareceram e rigidamente leram declarações de boa vontade e amizade.

As três redes nacionais escolheram diferentes estratégias. A ABC ignorou a visita. A NBC fez dela um pretexto para um comentário de John Chancellor sobre o que os EUA podiam aprender com o investimento do Japão em pesquisa e desenvolvimento. De sua parte, a CBS enfocou a declaração de Bush sobre a saúde e fez dela tanto um exemplo de um evento fracassado quanto parte de uma história separada e maior sobre as aparentes dificuldades que a administração Bush estava encontrando em relação a alguns indicados:

DAN RATHER: O Presidente Bush planejou demonstrar suas credenciais e experiência em política externa ao se encontrar com o Primeiro Ministro do Japão, Takeshita. Em lugar disso, como relata o correspondente da CBS Lesley Stahl, o Sr. Bush foi assolado por perguntas sobre a ética de alguns de seus indicados para altos cargos e por perguntas sobre sua própria saúde.

LESLEY STAHL: O Presidente Bush vem encontrando problemas para transmitir sua mensagem. Os planos bem claros para hoje: enfatizar a importância das relações entre os EUA e o Japão com seu primeiro visitante estrangeiro, o Primeiro Ministro Takeshita - mas o que foi perguntado a Bush? Como está sua saúde.

BUSH: Um homem totalmente novo. Tudo bem. Totalmente recuperado.

STAHL: Mais perguntas. E a conduta pessoal de John Tower? O porta-voz da Casa Branca disse que o Presidente tinha confiança em Tower e pede pronta consideração de sua indicação. E mais perguntas sobre outros indicados - questões éticas que confundem a mensagem central dos primeiros treze dias do mandato do Presidente Bush, a importância da ética no governo (...). (CBS Evening News, 2 de fevereiro, 1989)

O texto de Stahl, de 1989, pode ser um exemplo extremamente forte de iniciativa do repórter diante de um material pouco atraente. Mas lembra uma 
feliz observação de Todd Gitlin em seu famoso estudo sobre os Students for a democratic society (SDS): a notícia consiste em "descontextualização" (Gitlin, 1980, cap. 8). Ainda que claramente a capacidade de os repórteres tirarem um evento de seu contexto original e o colocarem num contexto próprio seja muito maior com um grupo relativamente sem poder como o SDS, funcionários importantes como presidentes estão longe de ser imunes ao mesmo processo.

Em seu esboço da dinâmica do ciclo de cobertura dada à nova esquerda, Gitlin também nos lembra de que o processo de produção da notícia não é infenso a atores políticos menos poderosos, inclusive não oficiais como os movimentos sociais (Gitlin, 1980, passim, esp. p. 25-31) ) $^{35}$ O SDS foi inicialmente ignorado; não procurava o noticiário e os repórteres não o consideravam importante ou digno de figurar. Acabou ganhando publicidade em histórias de "descoberta". Os repórteres cobrindo o SDS eram simpáticos ao movimento, certamente, mas foram capazes de "vender" as histórias a seus superiores expondo algo inteiramente novo e atraente para os valores de novidade, cor e drama. ${ }^{36}$ Essas histórias provocaram críticas azedas de fontes autorizadas, como o senador conservador John Stennis, ou o Procurador Geral dos EUA Nicholas Katzenbach. A cobertura virou aviltamento (à medida que os funcionários acabaram por usar seu maior acesso aos noticiários) e simplificou um programa complexo reduzindo-o a uma posição antiguerra do Vietnã. O SDS virou notícia "velha" mais rápido que os funcionários. Com os ativistas recentemente atraídos ao movimento pela imagem radical disseminada pelos noticiários e buscando publicidade cada vez mais cara para organizar-se, o SDS polarizou-se, com uma ala tornando-se mais extrema e teatral para obter cobertura. Finalmente, em parte como resposta a essa polarização e em parte (na esteira da ofensiva do Tet) porque a opinião da elite se dividiu sobre a guerra, a mídia ajudou a valorizar uma alternativa moderada, que recebeu cobertura favorável e lhe permitiu entrar no debate como ator autorizado.

Em outras palavras, a mídia noticiosa não corta completamente os ativistas não oficiais, mas o acesso deles é escasso no tempo e limitado no alcance.

\footnotetext{
35 O próprio Gitlin não afirma que tal ciclo ocorre, dado que essas fases empiricamente se sobrepõem consideravelmente. De qualquer maneira, como modelo geral das interações dos movimentos sociais com a mídia, o modelo promete, e a evidência atual a partir de outros movimentos também parece adequar-se ao modelo.

36 Ver a discussão da matéria de primeira página de Fred Powledge no New York Times, e do longo excerto na CBS, produzido por Stanhope Gould e relatado por Alexander Kendrick, em Gitlin (1980; respectivamente, p. 35-40 e 85-89).
} 
Os funcionários têm maior acesso em bases regulares para chamar a atenção para suas questões, preocupações e eventos, e para obter uma cobertura mais próxima de seus próprios termos. Mas o domínio oficial da negociação do processo não se estende ao conteúdo. Em suma, o duplo padrão do noticiário (importante e interessante) gera um modo de dividir o trabalho do produto do noticiário. As fontes oficiais parecem ter maior controle em garantir a importância, mas a mídia noticiosa é mais influente em definir o interesse. Essa divisão do trabalho foi bem captada por uma placa que aparecia na mesa do chefe dos porta-vozes de Reagan, Larry Speakes: "Você não nos diz como encenar a notícia, e nós não lhe dizemos como cobri-la". Embora humorística, a placa de Speakes revela as áreas em que cada lado é supostamente dominante - e sugere que o noticiário é uma co-produção constante, ainda que raramente consciente, de funcionários públicos e jornalistas.

\section{Que tipo de instituição política?}

Se o jornalismo constitui então uma instituição política, que tipo de instituição política ele constitui? Embora a noção de Cater de um "quarto poder" seja estimulante, é aqui que ela começa a mostrar seus limites. ${ }^{37}$ Os três poderes, legislativo, executivo e judiciário, foram, afinal, instituídos pela Constituição, com regras precisas sobre como seus membros deveriam ser selecionados, seus mandatos, bem como seus poderes e responsabilidades - esperando que tomassem decisões impositivas para toda a polis e capacitando-os para isso. O mesmo simplesmente não vale para o jornalismo. É verdade, como vimos anteriormente, que a forma da mídia noticiosa americana pode depender centralmente de decisões governamentais. E, de fato, ela tem um lugar proeminente na Constituição por força da proteção da "liberdade de imprensa" no Bill of rights. E é também verdade que o jornalismo tem um forte impacto sobre os resultados políticos. Mas o fato de que a mídia foi instituída e é amplamente controlada por corporações privadas faz dela algo diferente de um poder governamental.

Em lugar disso, o jornalismo compartilha mais com duas outras instituições políticas: os partidos políticos e o sistema de grupos de interesse..$^{38} \mathrm{Em}$ cada

\footnotetext{
37 Agradeço a Douglas Arnold e Michael Shudson por terem me empurrado nessa direção.

${ }^{38}$ Felizmente, há uma grande e boa produção de trabalhos recentes sobre o sistema de partidos políticos e o de grupos de interesse nos EUA. As próximas seções se apoiam nessa literatura. Duas excelentes resenhas, e contribuições teóricas de grande valor em si mesmas, sobre partidos políticos são Epstein, (1986) e Aldrich (1995). Pesquisas mais focadas, que contestam persuasivamente a escola da "deca-
} 
caso, essas instituições políticas estão simultaneamente dentro e fora do governo. De fato, no caso dos partidos políticos, eles surgiram tão cedo na jovem República que pode ser seguro dizer que, a despeito da retórica antipartidos dos fundadores, o processo podia simplesmente não ter funcionado sem esses intermediários essenciais num sistema marcado pela separação de poderes.

$\mathrm{Na}$ base, os meios noticiosos são associações privadas e, portanto, pelo menos parcialmente independentes do governo. Mas, como vimos, eles são profundamente afetados pelo patrocínio, subsídios e proteção oficial e reconhecimento legal. Muito disso vale também para os partidos políticos e grupos de interesse. No caso dos partidos políticos, suas regras são essencialmente formuladas por políticos, a ponto de que podem ser pensados como extensões de outras instituições políticas. ${ }^{39}$ Como disse o cientista político Leon Epstein, o reconhecimento legal e a regulamentação do papel dos partidos na seleção e financiamento de candidatos aos diversos postos significou que "os americanos deixaram de tratar seus principais partidos como associações privadas e os converteram em serviços públicos, quando não agencias do governo" (Epstein, 1986, p. 7). ${ }^{40}$

Até os grupos de interesse, que a ciência política alguma vez viu como expressões quase espontâneas de queixas sociais e políticas, surgem até certo ponto por causa do apoio e patrocínio governamental. A expansão da responsabilidade federal no século XX criou clientelas que procuraram proteger seus programas, mas, de maneira mais direta, o governo federal muitas vezes instiga grupos de conselheiros que ajudam a mobilizar um grupo desorganizado, dá incentivos tributários a grupos que não buscam lucros, dá recursos para projetos e assume parte das despesas com subsídios postais (Walker, 1991, p. 29-33). De fato, funcionários do governo e grupos de interesse estão tão imbricados e são tão interdependentes que às vezes é difícil saber quem está de qual lado.

dência dos partidos" gerada pelos estudos eleitorais e observam a crescente atividade dos partidos enquanto organizações e dentro de outras instituições, incluem Cotter, Gibson, Bibby e Huckshorn (1984); Herrnson (1988); e Rohde (1991).

Os três maiores projetos de pesquisa dos anos oitenta sobre o sistema de grupos de interesse são indispensáveis; estão bem apresentados em Schlozman e Tierney (1986); Walker Jr. (1991); e Heinz, Laumann, Nelson e Salisbury (1993).

39 Ver a discussão de Aldrich (1995) sobre o partido político como uma "instituição endógena".

40 No capítulo 6, tendo rejeitado termos como "quase governamental", "agência do estado", "governamentalizado" ou "quase público", Epstein volta-se para "serviço público", que "sugere uma agência desempenhando um serviço em que o público tem um interesse especial suficiente para justificar o controle regulador por parte do governo, junto com a extensão de privilégios legais, mas não propriedade governamental ou administração de todas as atividades da agência" (Epstein, 1986, p. 157). 
Ademais, podemos e devemos falar do sistema partidário como uma instituição e do sistema de grupos de interesse como uma instituição, cada uma delas apresentando apenas certas oportunidades para (e vieses contra) mobilização e ação. ${ }^{41}$ Assim como o jornalismo, o partido político e o grupo de interesses são institucionais. Eles procedem tanto por regras e regulamentos explícitos quanto por suposições sobre como os partidos e os grupos de interesse devem atuar, estendendo-se assim no espaço e no tempo. E espera-se também que desempenhem um papel político e social central na articulação e agregação de interesses e reclamações políticos.

Assim, o jornalismo pode ser uma instituição política, mas mais próxima das instituições intermediárias do partido e do grupo de interesses que dos três poderes, legislativo, executivo e judiciário. Mas há uma distinção-chave entre o jornalismo, de um lado, e o partido e o grupo de interesses, de outro: estes são formados e mantidos para a perseguição estratégica coletiva de objetivos políticos explícitos. O jornalismo (pelo menos desde o desaparecimento da imprensa partidária no século dezenove) não o é. Em comparação com a política explícita do partido e grupo de interesses, a política, o poder e o impacto do jornalismo bem podem ser implícitos e ocultos, até mesmo (ou especialmente) de seus próprios praticantes.

\section{Conclusão}

Qual é então a política do jornalismo americano? Que "alocação impositiva de valores" flui do envolvimento do jornalismo nos processos políticos? É claro que tal impacto político não começa nem termina com as atitudes e visões de mundo individuais dos jornalistas. Indicações das posições anti-autoritárias, liberais ou de apoio a candidatos democratas por parte dos repórteres podem não significar muito para o produto final do noticiário, dado seu bem documentado e árduo trabalho para apagar sua própria presença na

\footnotetext{
${ }^{41}$ Falar do sistema partidário como uma instituição apenas é facilmente aceitável, dados os modos comuns e imitativos em que os partidos evoluem, e dado o consenso dos pesquisadores sobre uma sucessão histórica de sistemas partidários. Eu esperaria mais resistência à ideia do sistema de grupos de interesse como uma instituição. Embora espaço e tempo me impeçam de aprofundar esse ponto, vale lembrar como Schattschneider (1960) esboçou o viés generalizado do que chamou de "sistema de pressões", ou como Walker (1991, p. 10, 14) argumentou: "O sistema mais amplo de grupos de interesse tem uma estrutura relativamente estável na qual as associações mantêm papéis e posições ideológicas identificáveis (...). O sistema de grupos de interesse fornece, numa sociedade cada vez mais complexa, um mecanismo através do qual questões e ideias novas podem ser oferecidas como possíveis novos elementos na agenda política nacional".
} 
história e também para chegar a algo próximo da objetividade. Mas, como vimos, na busca da objetividade, os repórteres acabam por acrescentar um viés particular à notícia - um viés estrutural, nos termos de Hofstetter, e não um viés explicitamente político - que favorece apenas certos atores, eventos, programas e questões.

O viés político mais permanente dos noticiários é claramente sua concentração nos eventos, ideias, preocupações, estratégias e na política de funcionários públicos poderosos. Essa gravitação na direção da oficialidade é o que faz com que o jornalismo não seja meramente político, mas governamental. A disponibilidade e a presença do jornalismo, tanto dentro das instituições quanto dentro do governo como um todo, leva os funcionários a pensar nele como um apoio potencial para atingir seus objetivos e assistir à conversão do jornalismo numa "instituição de governança".

Mas, como vimos, esse apoio raramente vem sem um custo. Mais importante: a propriedade privada da mídia e a crescente orientação ao lucro das organizações noticiosas fornecem algo como um contrapeso ao poder oficial. Os jornalistas aplicam outros padrões de avaliação de notícias além da importância a fim de manter o público interessado e, portanto, de manter a audiência sintonizada e os leitores fiéis. A autoridade dos funcionários, tal como representada nos noticiários, depende, em boa parte, da capacidade e disposição de tais atores políticos de adequarem suas atividades aos valores de produção das notícias. Se não o fizerem - como já observamos - correm o risco de perder o controle de sua agenda e/ou ser retratados em termos negativos. E, de fato, os noticiários americanos - em maior medida que seus equivalentes europeus - tendem a não manter uma distância consistente das fontes que cobrem, mas vacilam mais amplamente entre notícias que reforçam os objetivos dos funcionários e outras que os enfraquecem. ${ }^{42}$

O jornalismo faz assim parte do que o cientista político Richard Neustadt descreveu como "instituições separadas que compartilham poder". Embora

\footnotetext{
42 A observação talvez apareça melhor na comparação dos noticiários de televisão americanos e italianos relatados em Hallin e Mancini (1984). Outro bom indicador dessa tendência é uma análise comparativa entre a cobertura de televisão da eleição presidencial americana de 1984 e a eleição geral britânica de 1983. Enquanto 69\% das histórias da eleição britânica pertenciam à categoria "direta/descritiva" ou "mista", apenas 44\% das americanas pertenciam a essa categoria; $9 \%$ das histórias britânicas foram consideradas "pejorativas" e 5\% "reforçadoras", comparadas com 34\% e 22\% das americanas, respectivamente. Em outras palavras, a cobertura da campanha americana de televisão se distingue da britânica não só pela maior negatividade, mas também por maior positividade. Ver Semetko et alii (1991, tabela 7.6).
} 
os noticiários muitas vezes atuem no reforço do poder oficial, eles também incentivam a apenas atuar de maneiras específicas. Isso não quer dizer que os repórteres são agentes da cidadania fiscalizando a autoridade política; longe disso. A autonomia profissional dos jornalistas significa que frequentemente eles não prestam muita atenção ao juízo dos leitores, particularmente porque podem afirmar que os leitores sabem de que informação gostam, mas podem não saber de que informação precisam. ${ }^{43}$ Além disso, lembre-se o contraste feito por Baldasty entre a imprensa partidária do começo do século dezenove, que via os cidadãos como eleitores potenciais, e a imprensa comercial de cem anos atrás, que os via como consumidores potenciais. Os anunciantes podem facilmente ver os noticiários como modos de aproximar o público de suas mensagens, onde as notícias seriam o recheio. Pode ser que o poder político seja contrabalançado pela lógica do mercado, com benefícios incertos para os cidadãos.

Além das inclinações oficiais das notícias, há certo número de vieses mantidos pela pressão comercial para atrair e manter audiências que afetam a "alocação impositiva de valores". Seguindo Tuchman, a principal necessidade é converter os acontecimentos primeiro em eventos e então em notícias; e, ao fazê-lo, não só se transforma acontecimentos em histórias, mas também se tira o acontecimento de seu contexto inicial, colocando-o em outro contexto de escolha do jornalista. Em termos políticos, isso significa que as questões e acontecimentos que não se tornam narrativas com facilidade serão provavelmente postos de lado em favor daqueles que o fazem. Um bom exemplo vem das seis reportagens investigativas estudadas pela equipe de pesquisadores da Northwestern University. Um grupo de interesse reformista capturou a atenção dos repórteres com evidências de como asilos fraudavam o Medicare, mas esse ângulo foi afinal transformado numa reportagem da NBC sobre como os asilos abusavam dos pacientes - em parte por causa da necessidade de vilões e vítimas claros, em parte pela incapacidade de apresentar visualmente a fraude. Como disse o produtor executivo do noticiário da NBC quando o produtor revelou a fraude: "É só muito complicado. Onde estão as vítimas?" (Protess et alii, 1991, cap. 3, p. 82).

${ }^{43}$ As atitudes condescendentes dos repórteres em relação a seu público (e sua falta de disposição de aprender mais sobre ele) estão bem descritas em Darnton (1975); Gans (1979, cap. 7); e Burgoon et alii (1982, cap. 5). 
As necessidades que os repórteres têm de construir uma história a partir do material que lhes é oferecido e, simultaneamente, distanciar-se da responsabilidade política de transmitir essa informação significa que eles encontram meios de mostrar que não são meras extensões do governo e que devem imaginar como transformar um material pouco promissor numa história digna de ser publicada ou transmitida. As histórias recorrentes parecem girar em torno de manipulação política e problemas políticos, que são reportagens diretas e constituem um foco continuado fácil para contextualizar, interpretar e explicar os eventos do dia em relação a histórias produzidas no dia anterior, antecipando o que provavelmente acontecerá no dia seguinte. Ademais, uma história de fracasso político (p. ex., Bush "com problema de passar sua mensagem”, acima) é uma história fácil à qual retornar no caso de os funcionários não corresponderem às expectativas da narrativa.

A consequência tem sido a maior negatividade nas notícias em geral e particularmente nas histórias iniciadas pelos jornalistas. ${ }^{44}$ Até histórias positivas no geral podem chamar a atenção para a natureza intencional dos eventos encenados e/ou levantar dúvidas quanto aos motivos dos atores (geralmente atribuídos à pura política) e sua efetividade.

Acrescente-se às demandas da história os valores padrão de produção da notícia: deve ser oportuna, concisa, facilmente descritível, dramática, cheia de cor e visualizável. Outra vez, as questões, interesses e eventos que não se ajustem a esses critérios deverão ser transformados para se ajustarem, a fim de não serem excluídos do noticiário. Em especial, podemos ver a alocação de valores políticos do jornalismo observando que histórias e que elementos das histórias não recebem cobertura.

Oportunidade é um dos critérios mais antigos do noticiário, mas funciona a favor de apenas algumas questões, pois condições mais duráveis são simplesmente consideradas como notícias velhas. A atenção à oportunidade significa que as notícias são mais episódicas que analíticas. O cientista político Shanto Iyengar demonstrou numa série de experimentos que o relato episódico leva a um entendimento fragmentário por parte das pessoas e menos responsabilização do governo (Iyengar, 1991). Em outras palavras, a

\footnotetext{
44 Patterson (1993) apresenta a melhor informação sobre a crescente negatividade do jornalismo. Em outro lugar, um grupo de autores, inclusive eu mesmo, mostrou que a cobertura dos candidatos durante a campanha eleitoral de 1992 foi significativamente mais negativa nas histórias iniciadas pelos jornalistas. Histórias iniciadas por jornalistas foram em toda a mídia os fatores determinantes mais consistentes do tom em relação aos candidatos; Just et alii, (1996, p. 111).
} 
preocupação constante com o tempo presente, e com o que é novo e não o que é constante, nega a atenção do noticiário a problemas sociais pré-existentes, desencorajando soluções.

Os atores políticos às vezes contornam esse problema encenando um evento que lhes forneça um "pretexto" momentâneo e, portanto, uma oportunidade para falar sobre uma condição subjacente. Assim, presidentes fazem discursos, membros do Congresso convocam audiências, ativistas organizam comícios e demonstrações, e assim por diante. O problema é que o evento deve atingir não só os padrões de importância - e será tanto mais importante quanto mais fontes autorizadas estiverem envolvidas - mas também os valores de produção.

Se o evento lida com um problema complexo ou, ainda pior, com uma série de problemas, terá dificuldades com jornalistas que procuram algo fácil de descrever, e preferivelmente uma fácil divisão entre protagonistas e antagonistas. De maneira semelhante, discursos que não têm elementos de áudio incisivos, vivazes e muito curtos (em geral de menos de dez segundos) que possam ser extraídos são desfavorecidos em relação a aqueles que os têm; consequentemente, os oradores que querem chegar ao noticiário têm que construir sua comunicação em termos de elementos de áudio. E, finalmente, dado que muitos problemas políticos são estáticos, pálidos, e abstratos, eles podem ser evitados dada a exigência do jornalismo por drama, cor e boas imagens. Não é surpreendente que tanta atenção seja dada não só ao tipo certo de evento mas hoje em dia também ao tipo certo de suporte que transmita a mensagem visualmente. A busca por esse tipo de suporte atinge às vezes dimensões quase cômicas. No verão de 1995, por exemplo, a Procuradora Geral Janet Reno testemunhava diante de um comitê da Câmara sobre a decisão do governo no ano anterior de atacar, com gás lacrimogêneo, o Ramo Davidiano perto de Waco, Texas; esse ataque precedeu um incêndio que matou a maioria dos moradores. Quando um membro Republicano da Câmara ([John] Mica, da Florida) começou a interrogar Reno, um dos assessores dela levou uma máscara de gás e a colocou à frente dela; com um olhar frio para o assessor, Reno a pôs no chão, e o assessor voltou a colocá-la sobre a mesa. Esse vai e volta continuou algum tempo, até que Reno finalmente levantou a máscara de gás, ponto em que os fotógrafos bateram as fotos. A ironia de tudo é que, embora Mica pudesse ter alcançado seu objetivo pressionando Reno e ligando-a ao uso das máscaras, a foto, amplamente reproduzida no 
dia seguinte em muitos jornais, parecia ter pouco a ver com as histórias que a acompanhavam.

Esses vieses são duplamente problemáticos. Eles não afetam apenas as questões, problemas e visões de mundo que os cidadãos são convidados a contemplar; podem também empurrar os atores políticos, agora interessados em chegar aos noticiários como forma de alcançar poder e atingir objetivos políticos, na direção de fenômenos políticos que se ajustem aos padrões do que vale a pena ser publicado. Tomem-se as palavras do líder da Câmara Newt Gingrich numa entrevista concedida ao USA Today em 1995. Quando os entrevistadores lhe perguntaram sobre sua retórica frequentemente colorida e extremada, ele respondeu,

Parte da razão que eu uso linguagem forte é porque vocês vão pegá-la (...). Convençam seus colegas a dar-me cobertura sendo calmo, e eu estarei calmo. Vocês querem cobrir nove segundos, eu lhes darei nove segundos, porque esse é o requisito competitivo (...). Eu simplesmente tentei aprender minha metade do negócio de vocês. (USA Today, 7 de junho, 1995)

A última frase capta o tema-chave deste texto: que a notícia é uma coprodução das fontes (em geral funcionários públicos) e dos jornalistas, mas que as fontes não podem simplesmente estalar os dedos e fazer notícias por conta própria. Em lugar disso, a notícia é uma re-elaboração de ações, eventos e declarações oficiais, à luz dos valores de produção. Esses valores de produção favorecem tipos particulares de notícias e informação em detrimento de outros, e acabam por dotar as notícias de uma política particular.

Mas, além disso, essa coprodução empurra os atores políticos a prever as necessidades das notícias projetando o que dirão e farão. No processo, não apenas o jornalismo, mas também a política, ficam obcecados por questões que possam tornar-se oportunas, concisas, facilmente descritíveis, dramáticas, cheias de cor e visualizáveis. ${ }^{45}$ Embora esses critérios - largamente compartilhados entre jornalistas numa variedade de áreas - pareçam neutros em termos de conteúdo, eles não o são. A política, segue-se, deve ser simples e direta, com dois lados para cada história, e as diferenças devem ser facilmente solucionáveis. Espera-se então que os atores políticos sejam diretos e

45 Kernell chega a uma conclusão semelhante, embora se refira mais ao impacto dos discursos que ao da produção de notícias (e da busca de histórias). Ver Kernell (1993, esp. cap. 8). 
consistentes. Da mesma forma, a ação é boa em si mesma e por si mesma; a inação é tomada como um signo de incompetência, má fé e/ou mesquinharia. Supõe-se que a evidência de problemas não seja difícil de resolver, dada a presença de indicadores claros e visíveis. Como os políticos são muitas vezes ambíguos e flexíveis, querem lidar com políticas e questões e não com histórias dramáticas, e como seus temas são complexos e abstratos, os valores de produção podem ser um obstáculo para os atores políticos e para a política.

$\mathrm{Na}$ medida em que os atores políticos precisam cada vez mais de publicidade para colocar suas questões na agenda política e atingir seus objetivos, devem conformar suas atividades aos valores de produção das notícias, e a política se seguirá daí. Mas, por que os atores políticos estão interessados em “aprender minha metade do negócio" dos jornalistas? Isso é outro assunto.

\section{Referências bibliográficas}

ADATTO, Kiku. 1990. "Sound-bite democracy: network evening news presidential coverage, 1968 and 1988”. Research Paper R-2, Joan Shorenstein Barone Center on the Press, Politics and Public Policy, Kennedy School of Government, Harvard University (reimpresso como parte de Picture perfect. New York: Basic Books, 1992).

ALDRICH, John H. 1995. Why parties? the origin and transformation of political parties in America. Chicago: The University of Chicago Press. ALTHEIDE, David L. 1976. Creating reality: how TV news distorts events. Bervely Hills (CA): Sage.

BENNETT, W. Lance. 1990. “Toward a theory of press-state relations”. Journal of Communication, n. 40, p. 103-125.

\& PALETZ, David L. (eds.). 1994. Taken by storm: the media, public opinion and U.S. foreign politcy in the Gulf War. Chicago: University of Chicago Press.

BERKOWITZ, Dan. 1987. "TV new, sources and news channels: a study in agenda building". Journalism Quarterly, n. 64, p. 508-513.

BLUMLER, Jay G. \& GUREVITCH, Michael. 1981. "Politicians and the press: an essay on role relationships". In: NIMMO, Dan D. \& SANDERS, Keith R. (orgs.). Handbook of political communication. Beverly Hills, CA: Sage. BROWN, J. D.; BYBEE, C. R.; WEARDON, S.T. \& STRAUGHAN, D. M. 1987. "Invisible power: newspaper news sources and the limits of diversity”. Journalism Quarterly, n. 64, p. 45-54. 
BURGOON, Judee K.; BURGOON, Michael \& ATKIN, Charles K. 1982. The world of the working journalist. New York: Newspaper Advertising Bureau. COHEN, Akiba A.; ADONI, Hanna \& BANTZ, Charles R. 1990. Social conflict and television news. Newbury Park, CA: Sage.

CONNOLLY, William E. 1983. The terms of political discourse. $2^{\text {a }}$ ed. Princeton, N.J., Princeton University Press.

COOK, Timothy. 1989. Making laws \& making news: media strategies in the U.S. House of Representatives. Washington: Brookings.

1994. "Domesticating a crisis: Washington newsbeats and network news after the Iraqi invasion of Kuwait”. In: BENNETT, W. Lance \& PELETZ, David L. (orgs.). Taken by storm: the media, public opinion and US foreign policy in the gulf war. Chicago: The University of Chicago Press. . 1996. “The negotiation of newsworthiness". In: CRIGLER, Ann N. (ed.). The psychology of political communication. Ann Arbor: University of Michigan Press.

CORNWELL JR., Elmer E. 1965. Presidential leadership and public opinion. Bloomington: University of Indiana Press.

COTTER, Cornelius P.; GIBSON, James L.; BIBBY, John F. \& HUCKSHORN, Robert J. 1984. Party organizations in American politics. New York: Praeger.

CROUSE, Timothy. 1973. The boys on the bus: riding with campaign press corps. New York: Ballantine.

DAHL, Robert A. 1963. Modern political analysis. Englewood Cliffs (NJ): Prentice Hall.

DARNTON, Robert. 1975. "Writing news and telling stories". Daedalus, v. 104, n. 2, p. 175-194.

DIAMOND, Edwin. 1995. Behind the times, ed. rev. Chicago: The University of Chicago Press.

EASTON, David. 1965. A framework for political analysis. Englewood Cliffs (NJ): Prentice Hall.

EPSTEIN, Edward Jay. 1974. News from nowhere: television and the news. New York: Vintage Books.

EPSTEIN, Leon D. 1986. Political parties in the American mold. Madison: University of Wisconsin Press.

FISHMAN, Mark. 1980. Manufacturing the news. Austin: University of Texas Press. 
GANS, Herbert J. 1979. Deciding what's news. NewYork: Random House. GITLIN, Todd. 1980. The whole world is watching: mass media in the making \& unmaking of the new left. Berkeley: University of California Press.

GLASSER, Theodore L. 1991. "Journalism's glassy essence". Journalism and Mass Communication Quarterly, n. 73, p. 784-786.

GOLDENBERG, Edie N. 1975. Making the papers: the access of resource-poor groups to the metropolitan press. Lexington (MA): D.C. Heath.

GOTTLIEB, Martin. 1989. "Dangerous liaisons: journalists and the sources". Columbia Journalism Review, v. 28, n. 2, p. 21-35.

GROSSMAN, Michael Baruch \& KUMAR, Martha Joynt. 1980. Portraying the president: the White House and the news media. Baltimore: Johns Hopkins University Press.

GULLIVER, Philip H. 1979. Disputes and negotiations: a cross-cultural perspective. New York: Academic Press.

HALL, John A. \& IKENBERRY, G. John. 1989. The State. Minneapolis: University of Minnesota Press.

HALLIN, Daniell C. 1986. The "uncensored war": the media and Vietnam. New York: Oxford University Press.

\& MANCINI, Paolo. 1984. "Speaking of the president: political structure and representational form in U.S. and Italian television news". Theory and Society, n. 13, p. 829-850.

HEINZ, John P.; LAUMANN, Edward O.; NELSON, Robert L. \& SALISBURY, Robert H. 1993. The hollow core: private interests in national policy making. Cambridge, MA: Harvard University Press.

HESS, Stephen. 1981. The Washington reporters. Washington (DC): Brookings Institution.

HERRNSON, Paul. 1988. Party campaigning in the 1980s. Cambridge (MA): Harvard University Press.

HERTSGAARD, Mark. 1988. On bended knee: the press and the Reagan presidency. New York: Farrar, Strauss and Giroux.

HOFSTETTER, C. Richard. 1976. Bias in the news: network television coverage of the 1972 election campaign. Columbus: Ohio State University Press. . 1978. "News bias in the 1972 campaign: a cross-media comparison". Journalism Monographs, n. 58.

HUITT, Ralph K. \& PEABODY, Robert. 1969. Congress: two decades of analysis. New York: Harper and Row. 
IYENGAR, Shanto. 1991. Is anyone responsible? How television frames political issues. Chicago: The University of Chicago Press.

JUST, Marion R.; CRIGLER, Ann N.; ALGER, Dean E.; COOK, Timothy

E.; KERN, Montague \& WEST, Darrell M. 1996. Crosstalk: citizens, candidates, and the media in a presidential campaign. Chicago: University of Chicago Press.

KERBEL, Matthew Robert. 1997. Edited for television: Cnn, Abc, and American presidential elections. $2^{\text {a }}$ ed. New York: Bookseller/Book Smart.

KERNELL, Samuel. 1993. Going public: new strategies of presidential leadership. Washington: CQ Press.

KIMBALL, Penn. 1994. Downsizing the news: network cutbacks in the national capital. Washington (DC): Woodrow Wilson Center Press.

LAWRENCE, Regina. 1996. "Accidents, icons and indexing: the dynamics of news coverage of police use of force". Political Communication, n. 13, p. 437-454.

LEVINE, Grace Ferrari. 1977. "Learned helplessness and the evening news". Journal of Communication, n. 27, p.100-105;

LEVINE, Grace Ferrari. 1986. "Learned helplessness in local TV news". Journalism Quarterly, n. 63, p. 12-18.

MANHEIM, Jarol B. 1979. “The honeymoon's over”. Journal of Politics, n. 41, p. $55-74$.

MANOFF, Robert Karl \& SCHUDSON, Michael (eds.). 1986. Reading the news. New York: Pantheon.

MATTHEUS, Donald R. 1960. US senators and their world. Chapel Hill: University of North Carolina Press.

McGERR, Michael. 1986. The decline of popular politics: the American North, 1865-1931. New York: Oxford University Press.

McMANUS, John H.1994. Market-driven journalism. Newbury Park (CA): Sage.

MERMIN, Jonathan. 1996. "Conflict in the sphere of consensus? Critical reporting on the Panama invasion and the gulf war". Political Communication, n. 13, p. 181-194.

MOLOTCH, Harvey \& LESTER, Marilyn. 1975. "Accidental news: the great oil spill as local occurrence and as national event". American Journal of Sociology, n. 81, p. 235-260.

PATTERSON, Thomas E. 1993. Out of order. New York: Knopf. 
PELETZ, David \& DUNN, Robert. 1969. "Press coverage of civil disorders: a case study of Winston-Salem, 1967”. Public Opinion Quarterly, n. 33, p. 328-345.

PHILLIPS, E. Barbara. 1976. "What is news? novelty without change". Journal of Communication, v. 26, n. 4, p. 87-92.

PROTESS, David L.; COOK, Fay Lomax; DOPPELT, Jack C.; ETTEMA, James S.; GORDON, Margaret T.; LEFF, Donna R. \& MILLER, Peter. 1991. The journalism of outrage: investigative reporting and agenda building in America. New York: Guilford Press.

PRUITT, Dean G. \& CARNEVALE, Peter J. 1993. Negotiation in social conflict. Pacific Grove (CA): Brooks/Cole.

ROBINSON, John \& LEVY, Mark. 1986. The main source: learning from television news. Beverly Hills (CA): Sage.

ROCKMAN, Bert A. 1987. “Government”. In: BOGDANOR, Vernon (org.). The blackwell encyclopedia of political institutions. New York: Basil Blackwell.

ROHDE, David W. 1991. Parties and leaders in the postreform house. Chicago: The University of Chicago Press.

RYAN, Charlotte. 1991. Prime time activism: media strategies for grassroots organizing. Boston: South End.

SCHANK, Roger C. 1990. Tell me a story: a new look at real and artificial memory. New York: Charles Scribner's Sons.

\& ABELSON, Robert. 1979. Scripts, plans, goals, and understanding. Hillsdale, NJ: Lawrence Erlbaum Associates.

SCHATTSCHNEIDER, Elmer Eric. 1960. The semi-sovereign people: a realist's view of democracy in America. New York: Holt, Rinehart, and Winston.

SCHLOZMAN, Kay Lehman \& TIERNEY, John. 1986. Organized interests and American democracy. New York: Harper and Row.

SCHUDSON, Michael. 1978. Discovering the news: a social history of American newspapers. New York: Basic Books.

SEMETKO, Holli A.; BLUMLER, Jay G.; GUREVITCH, Michael \&WEAVER, David H. 1991. The formation of campaign agendas: a comparative analysis of party and media roles in recent American and British elections. Hillsdake (NJ): Lawrence Erlbaum Associates.

SIGAL, Leon V. 1973. Reporters and officials: the organization and politics of newsmaking. Lexington, MA: D. C. Heath. 
SIGELMAN, Lee. 1973. "Reporting the news: an organizational analysis". American Journal of Sociology, n. 79, p. 132-151.

TILLY, Charles. "Revolutions and collective violence". In: GREENSTEIN, Fred I. \& POLSBY, Nelson W. (orgs.). Handbook of political science, vol. 3. Reading: Addison-Wesley.

SOLOSKI, John. 1989. "News reporting and professionalism: some constraints on the reporting of the news". Media, culture and society, n. 11, p. 207-228.

STEPAN, Alfred. 1978. The state and society. Princeton: Princeton University Press.

TUCHMAN, Gaye. 1978a. Making news: a study in the construction of reality. New York: Free Press.

TUCHMAN, Gaye. 1978b. "The newspaper as a social movement's resource”. In: TUCHMAN, Gaye; DANIELS, Arlene Kaplan \& BENET, James. Hearth and home: images of women in the mass media. Oxford: Oxford University Press.

WALKER JR., Jack L. 1991. Mobilizing interest groups in America: patrons, professions and social movements. Ann Arbor: University of Michigan Press. WEAVER, Paul H. 1972. "Is television news biased?”. Public Interest, n. 26, p. 57-74.

\section{Resumo}

Neste texto, Timothy Cook analisa o jornalismo político a partir de uma visão da mídia como instituição social singular. A produção da notícia é entendida como um processo coletivo definido pelas rotinas do jornalismo como instituição e pelas escolhas implícitas nessas rotinas, que são aceitas e reproduzidas no cotidiano de produção da notícia. A independência parcial do jornalismo em relação à política não impede, no entanto, que ele atue como instituição política e governamental. Além de disseminar as informações políticas, definindo o que é importante e o que é interessante, os jornalistas dão relevância aos atores políticos e certificam sua autoridade. O noticiário é o resultado de negociações conflituosas entre jornalistas e fontes, nas quais ganham peso, simultaneamente, as fontes oficiais e os valores inerentes às rotinas jornalísticas.

Palavras-chave: jornalismo político; mídia; governo; fontes oficiais; rotinas jornalísticas.

\section{Abstract}

In this text, Timothy Cook analyses political news from a point of view that considers media as a singular social institution. The production of news is understood as a collective 
process defined by the routines of journalism as an institution and by the choices implied in these routines that are accepted and reproduced in the everyday production of the news. The partial independence of news reporting relative to politics does not hinder, however, that the news function as a political and even governmental institution. Besides publishing political information, defining what is important and interesting; journalists give relevance political actors and certify their authority. The news is the result of conflicting relationships between journalists and sources, where the weight is balanced between official sources and the values inherent to journalistic routines.

Key words: political news; media; government; official sources; journalistic routines. 